
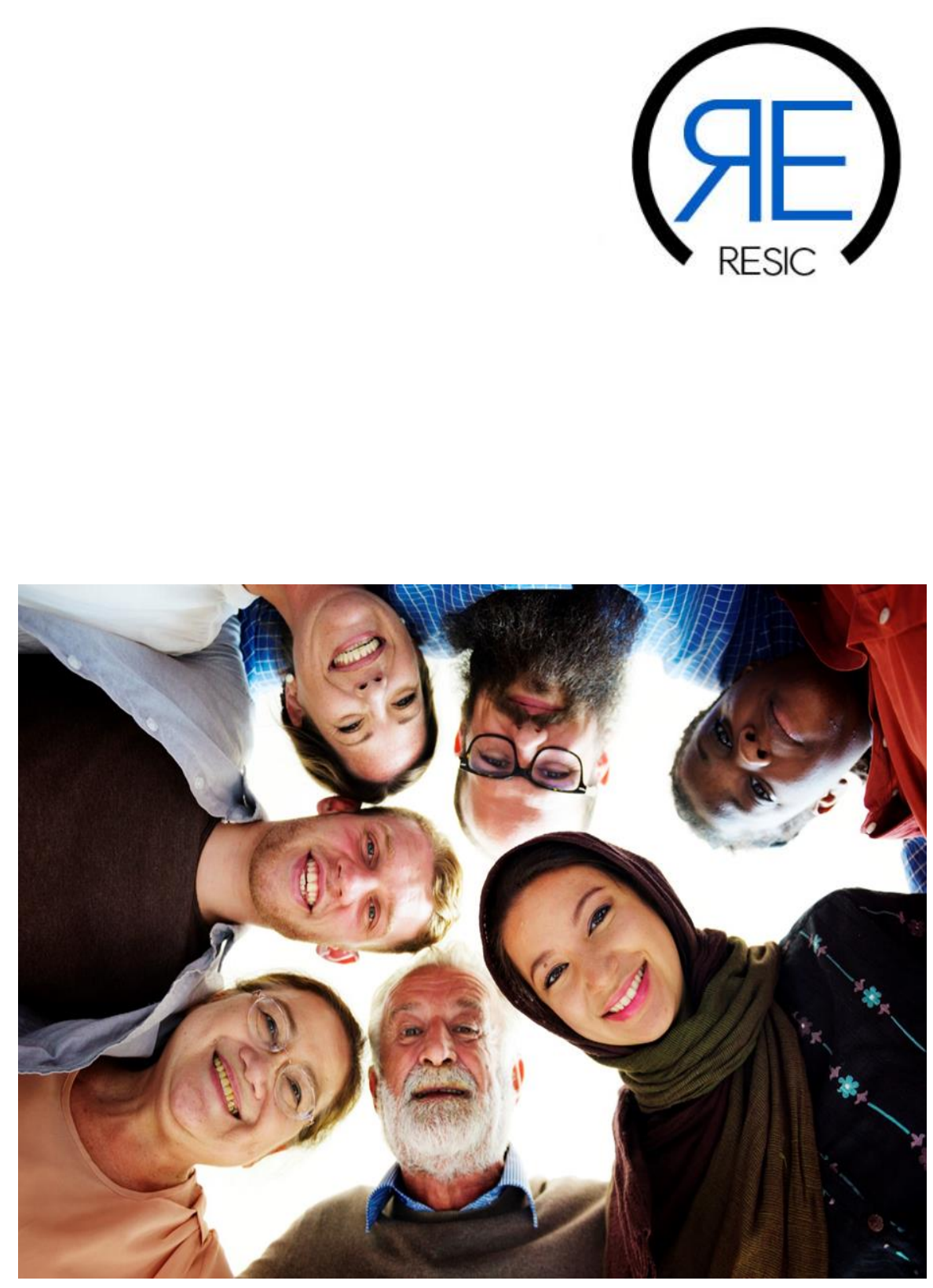

\title{
POLARISATION AND SOCIAL COHESION: THE AMBIVALENT POTENTIAL OF RELIGION IN DEMOCRATIC SOCIETIES
}

Findings of a representative survey on the social role of religious and social identities in Germany and Switzerland, 2019 



\section{POLARISATION AND SOCIAL COHESION:}

\section{THE AMBIVALENT POTENTIAL OF RELIGION IN DEMOCRATIC SOCIETIES}

Findings of a representative survey on the social role of religious and social identities in Germany and Switzerland, 2019 
Title: $\quad$ Polarisation and social cohesion: the ambivalent potential of religion in democratic societies. Findings of a representative survey on the social role of religious and social identities in Germany and Switzerland, 2019

Authors: Antonius Liedhegener, Gert Pickel, Anastas Odermatt, Alexander Yendell, Yvonne Jaeckel Front page: istockphoto.com / Rawpixel

Citation: Liedhegener, Antonius / Pickel, Gert / Odermatt, Anastas / Yendell, Alexander / Jaeckel, Yvonne: Polarisation and social cohesion: the ambivalent potential of religion in democratic societies. Findings of a representative survey on the social role of religious and social identities in Germany and Switzerland in 2019 (research report). Lucerne / Leipzig 2021.

DOI: 10.5281/zenodo.3994628 (CH) / 10.36730/rtv.2020 (DE)

Copyright: CC-BY-NC: https://creativecommons.org/licenses/by-nc/4.0/

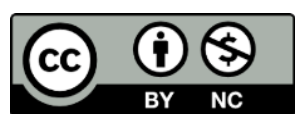

RESIC is a joint project of the universities:

GEORG-AUGUST-UNIVERSITÄT GÖTTINGEN

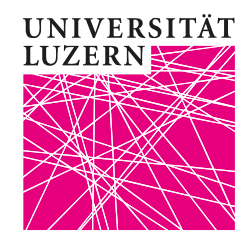

Sponsored by:

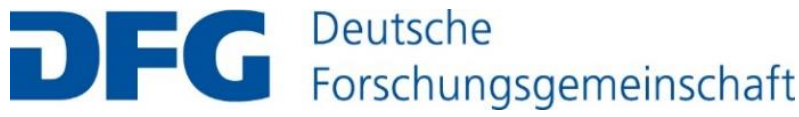




\section{Contents}

Abstract

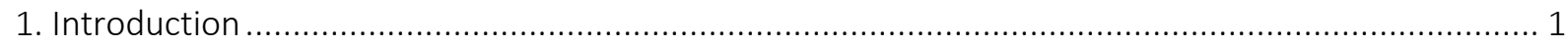

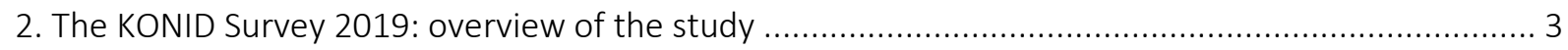

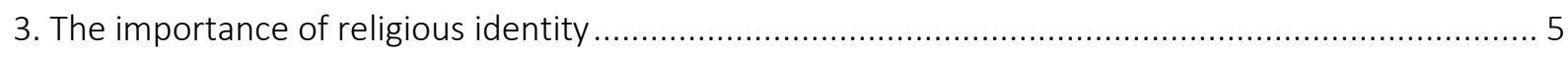

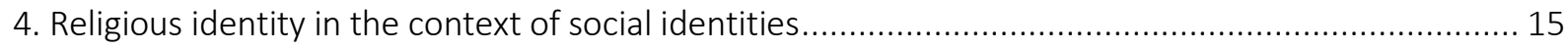

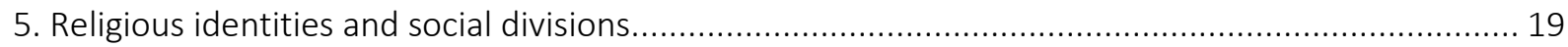

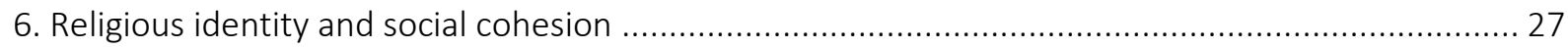

7. How religious identity structures society: five configurations of social identities in Germany and

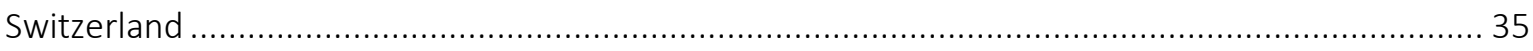

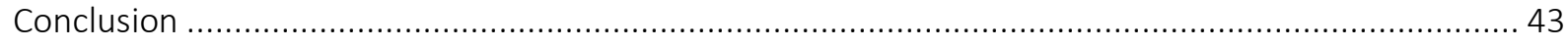

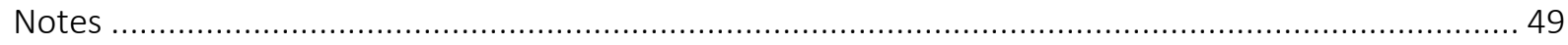

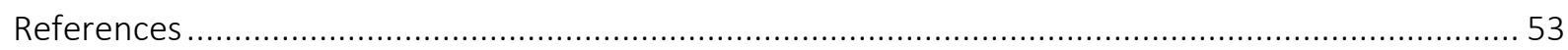

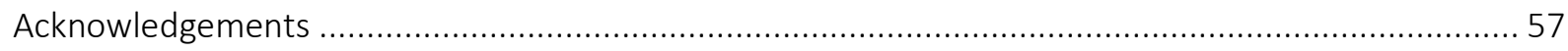




\title{
Polarisation and social cohesion: the ambivalent potential of religion in democratic societies.
}

\author{
Findings of a representative survey on the social role of religious and \\ social identities in Germany and Switzerland, 2019
}

\section{Abstract}

Western democracies are currently experiencing a renaissance of social identities. The appreciation of religious identities in public and politics is perhaps the most prominent expression of the growing social significance of social identities. There is also great public uncertainty about how to deal with religious affiliations and especially with Muslims. Does religion separate societies or does it promote the cohesion of democracies?

The new research approach of the KONID-project aims to identify religious identities in the context of their social references in a differentiated way and thus more precisely than before. Its first results are presented in this report. The research project "Configurations of Individual and Collective Religious Identities and their Potential for Civil Society (KONID)", funded by the German Research Foundation (DFG) and the Swiss National Science Foundation (SNSF), aims to describe the significance of religious affiliations and attributions to religious groups (such as "Catholics", "Jews", "Muslims" etc.) on the individual level as well as in society and its groups, and to analyse and explain the effects of religious identities on living together. For this purpose, religious identities are compared with other social identities that are important to people or by which they are divided into groups, and are examined in a country comparison between Germany and Switzerland.

The KONID Survey 2019 surveyed the significance of religion for social identities in a multi-thematic, country-comparative representative survey of the population in Germany and Switzerland aged 16 and older, paying particular attention to Muslim minorities. In both countries, more than 3,000 people were surveyed from spring to summer 2019.

The KONID Survey 2019 surveyed no fewer than 21 possible social identities and placed them in their social and religious contexts. The central findings are the following:

Religion is a formative and structuring factor for social identities in the complex societies of Germany and Switzerland. For many people, their religious affiliation is important as a social identity. In Germany, $57 \%$ of the population rate religion as an important social identity. In Switzerland, 50\% consider their religious identity to be important.

While identification with religion often plays a lesser role within the two major church traditions of Christianity, one's own religious identity is of central importance for members of free churches and Muslims in particular. After all, for about $30 \%$ of those who do not (any longer) belong to any religious community, the fact of not-belonging is important for their own social identity.

In both countries, however, religion is not the most important social identity. Above all, family affiliation and belonging to a circle of friends and acquaintances rank clearly before religion. In addition, it is striking how important engagement and voluntary work are for the self-image of those who volunteer. 
The social impact of religion as a social identity is ambivalent. Religion divides - and unites.

Religious social identities are the object and cause of discrimination. The extent of religious discrimination experienced in Germany and Switzerland is moderate overall, but discrimination is much more common for members of free churches and Muslims. At the same time, religion serves many people as a social identity that can be used to create social distance and to exclude others. About a quarter of Christians do not consider marrying non-Christians. Around $40 \%$ of Muslims reject non-Muslims as marriage partners. The rejection is even higher among members of free churches in Switzerland (53\%), but not in Germany (15\%).

The KONID Survey 2019 also surveyed how the interviewees draw the line between democratic community and religious truth. Privileging religious truths and views over the constitution and the willingness even to use violence for one's own faith are rare. If they do exist, then such positions are more pronounced among Muslims and members of free churches. The overall finding, however, is that a certain degree of agreement occurs across all religious denominations. The politically relevant problem is therefore to get a general overview of dogmatic or fundamentalist positions that tend to extremism and to address them together with the religious communities. In other words, this is not a genuine problem of "Islam" as a religion.

Religion is not only a source of problems. Religion is also socially productive. Religious affiliation and religiosity increase voluntary commitment. Religion-related voluntary commitment promotes contact between people who would otherwise not meet in everyday life. Such commitment can build bridges. The survey shows that those for whom their religious identity is important also regard interreligious dialogue as important. This dialogue is most strongly advocated by religious minorities and in particular by Muslim interviewees. Here a great potential becomes visible that is socially available for such a dialogue. Moreover, this potential rests in an almost complete consensus on the value of the right of freedom of religion in both countries. Consequently, religious diversity can connect and promote the society.

Particularly surprising is that despite the increasing complexity of the construction of social identities among individuals, religion in Germany and Switzerland is a factor in society as a whole that structures social identities in a lasting way. A cluster analysis shows five configurations of social identities for both countries, in which religion and community/nation are constitutive features to distinguish them. In particular, more research is needed here. 


\section{Introduction}

The public in Western democracies is unsettled: Is religion a driving force for conflicts and social divisions? Or are religions a central component of those factors that guarantee social cohesion and the functioning of democracy? Which religion, which religiosity, or which belief is detrimental to a democratic society, and which support and promote it? And - often discussed - is "Islam" per se politically problematic for democracy?

The findings of previous research on the new public role of religions in democratic societies are manifold - and contradictory. Social capital research shows that religion is among the socially productive forces: it encourages civic engagement and social trust among citizens. Therefore, religions contribute to the cohesion of democratic societies. ${ }^{1}$ Research on prejudice, on the other hand, argues that religion is frequently the cause and object of discrimination and exclusion. In this respect, religion and, above all, religious diversity primarily divide a society. ${ }^{2}$ In view of such contradictory findings, it is important to take a closer look at religion. It can be assumed that the significance of religion for an individual's identity varies considerably. Likewise, personal religiosity may be shaped differently among people. ${ }^{3}$

The new research approach of the project "Configurations of Individual and Collective Religious Identities and their Potential for Civil Society (KONID)" aims to identify religious identities in the context of their social relations more precisely than before. The first results of the project are presented in this report. The project is led by Antonius Liedhegener (Lucerne) and Gert Pickel (Leipzig). It is funded by the German Research Foundation (DFG) and the Swiss National Science Foundation (SNSF). The project aims to describe the significance of religious affiliations and attributions to religious groups (such as "the Catholics", "the Jews", "the Muslims", etc.) on the individual level as well as in society and its various groups. Furthermore, it seeks to analyse and explain the effects of religious identities on living together in democratic societies. This aim can only succeed when religious identities are compared with other social identities, either social identities that are important to people themselves or social identities by which they are divided into groups.

For this purpose, the German-Swiss research project KONID has developed a new survey instrument for measuring social identities. It captures the significance of social identities for the respondents, the recognition of such identities by the respondents' social environment, the respondents' willingness to differentiate themselves from other groups in society and, finally, the level of discrimination experienced by respondents in respect to their different social identities. In addition, the content and understanding of religious affiliation and religiosity are measured. This differentiated approach allows us to place religion as a social identity within the broader context of religion. Following Social Identity Theory, we understand social identities "as that part of the individuals' self-concept which derives from their knowledge of their membership of a social group (or groups) together with the value and emotional significance attached to this membership". ${ }^{4}$ The KONID Survey 2019 investigated as many as 21 possible social identities. The primary goal of the data analysis is to investigate configurations of social identities, i.e. to check for patterns in their occurrence and their combination among the respondents as well as in the population. Our report shows that such configurations do indeed exist, despite all growth of individualisation in Germany and Switzerland. Moreover, religion plays a key role in these newly found configurations of social identities. 


\section{The KONID Survey 2019: overview of the study}

The KONID Survey 2019 is a representative survey for Germany and Switzerland. It focuses on the following questions: (1) Are there patterns or configurations of religious and other social identities in both countries? If so, what are these? (2) How can their emergence be explained? (3) What effects do religious and other social identities have on civil society, political participation, and social cohesion? (4) How can these effects be explained?

For the first time, the representative survey of the KONID-project provides differentiated and directly comparable data for Germany and Switzerland on a whole range of social identities and their connection with religion. The following social categories were examined as being potentially relevant for identity-building and group-forming: age group; profession; being European; family; fan of sports club; voluntary work; circle of friends; country of birth; gender; place of origin (federal state, canton or nation where most of the childhood was spent); denomination; nationality; political orientation; neighbourhood affiliation; religious affiliation; social class; country region (language regions in Switzerland, East/West in Germany); inequality; place of residence; marital status; federal state or canton of residence. The survey thus covers social identities on the micro level such as family and circle of friends and acquaintances, the meso level such as involvement in associations and religious communities and belonging to regions and areas of the country, and the macro level such as religion, nation, and being European.

The KONID Survey 2019 and its two associated country research projects are part of the GermanSwiss research network "Social Groups and Religious Identities in Civil Society (RESIC)" (www.resic.info). The research network comprises two quantitative sub-projects (KONID) and two qualitative sub-projects. The qualitative projects, named "Migrant Communities, Religious Identities and Civil Society Involvement (MIE)", are dedicated to research on Muslim migrant communities of Bosnian origin and Catholic migrant communities of Croatian origin. The overall project follows a mixed-method approach. Together, the projects investigate the structure of social identities and the conditions of their emergence, the meaning and significance of migrant communities at the individual and the meso- or organisational level, as well as the effects of specific religious identities in civil society and politics. The RESIC-project was launched in mid-2018 and lasts three years. Its research speaks to the growing importance of civil society for liberal democracies and the continuing increase in religious diversity. Against this background, RESIC aims to fill the research gap regarding the content and effects of social identities of religious groups and communities and their religiosity.

Both country surveys are based on an identical questionnaire. The questionnaire has been newly developed. In addition, the survey instruments themselves were structured identically as much as possible. The data were collected from spring to summer 2019. Both surveys were conducted as online and telephone surveys (mixed mode). They were carried out by two professional opinion research institutes, aproxima (Weimar, Germany) and DemoSCOPE (Adligenswil, Switzerland). ${ }^{5}$ The KONID Survey 2019 covers the resident population over 16 years of age, regardless of nationality. The German representative survey has been extended by a special sample for Muslims of Turkish and Bosnian origin and Catholics of Croatian origin. Due to general national differences in sampling procedures, the Swiss survey contains an over-quota for Muslims in general and Muslims from Bosnia and Catholics of Croatian origin in particular. In addition, both surveys include an over-quota for younger age groups to allow for further special studies on youth and social identity formation. The German representative survey comprises 2,363 respondents. The additional sample of Turkish 
Muslims consists of 500 respondents. The Swiss representative survey has a total of 3,019 respondents. This number includes all over-quotas. Thus, the Swiss survey includes a representative sample of 485 Muslims. $^{6}$

Three methodological aspects are particularly important to the KONID Survey. Firstly, social identities must be asked for as specifically as possible in order to come close to the everyday life reality of the respondents. Religion as a social identity, for example, should not be asked for in a schematic, generalised way, such as: "How important is your religious affiliation to you?" Rather, the question about religious identity must refer to the individual's concrete group membership. Therefore, the KONID Survey uses sophisticated programming of its survey instrument: a great deal of information on demographics was collected at the beginning of the interview. This information was used to control the subsequent questions on social identity. For example, the question on religious identity shown or read to a person who is a member of the Catholic Church became: "We all have a range of different characteristics that make us the person who we are. Some of these are very important to us, others are not very important. How is it for you? How important are the following characteristics? ... to be Catholic".

Secondly, questions about social identity must be constructed as broadly as possible and without biases towards certain outcomes. In previous surveys, the questions often forced respondents to choose and rank only those three social identities that are most important to them. ${ }^{7}$ In contrast, the KONID Survey 2019 allowed respondents to rate up to 21 social identities separately on a 6point scale, without having to rank them. ${ }^{8}$

Thirdly, if statements are to be independent of the respondent's national or cultural origin and thereby representative for the total population over 16 years of age, the survey questionnaire must be available in multiple languages. Considering the high proportion of immigrants and especially the language problems of first-generation immigrants, the questions must be available in the languages not only of the majority population but also of the most common languages spoken among immigrant minorities. In Germany, the KONID Survey was offered in two languages - German and Turkish - since Turkey is by far the most common country of origin of Muslims in Germany. In Switzerland, the KONID Survey was available in eight different language versions: in German, French and Italian (being the national languages), as well as in English, Albanian, Bosnian, Croatian and Turkish, i.e. the common regions of origin of the special samples.

The country comparison of Germany and Switzerland was chosen for various reasons. Compared with the rest of Europe, the two countries are quite similar in terms of their level of economic and social development. Particularly important, both countries are Western European immigration countries. However, in terms of the political system and national culture, they show clear differences. These differences could become relevant to the perception of social identities. Thus, by comparing the two countries, we can assess which aspects of social identities and their configurations are more likely to be attributed to their common status as (highly) modern, complex societies, and which aspects are more likely to be based on national characteristics. Both can be found in the empirical data. 


\section{The importance of religious identity}

It has now become clear that the much-discussed return of religion in Europe is above all a return of religion into the political sphere. Religious identities have acquired a new significance in the public sphere, a significance that they did not have for a long time after the end of the old confessional milieus up to about 1970. In the increasingly secular societies of (not just) Germany and Switzerland, individualisation and immigration have generated a new diversity, and not least in terms of religion and other worldviews (Weltanschauungen). New group ascriptions, corresponding boundaries of social demarcation, and social discrimination based on religious affiliation have accompanied this more recent development. At the same time, the personal confrontation with religion and other systems of meaning - such as agnostic or atheistic beliefs - as well as the possible belonging to corresponding groups and communities, count among the fundamental decisions and points of reference from which people derive their self-image as social beings. However, religion is not the only source of self-understanding. It seems to be one of the main features of present times that social identities of all kinds can become the focal point of personal beliefs and lifestyles. ${ }^{9}$ The revaluation of religious identities is a notable expression of the growing importance of social identities in public and political life in general.

\section{Figure 3.1: Reported Importance of the Social Identity 'Religion'}

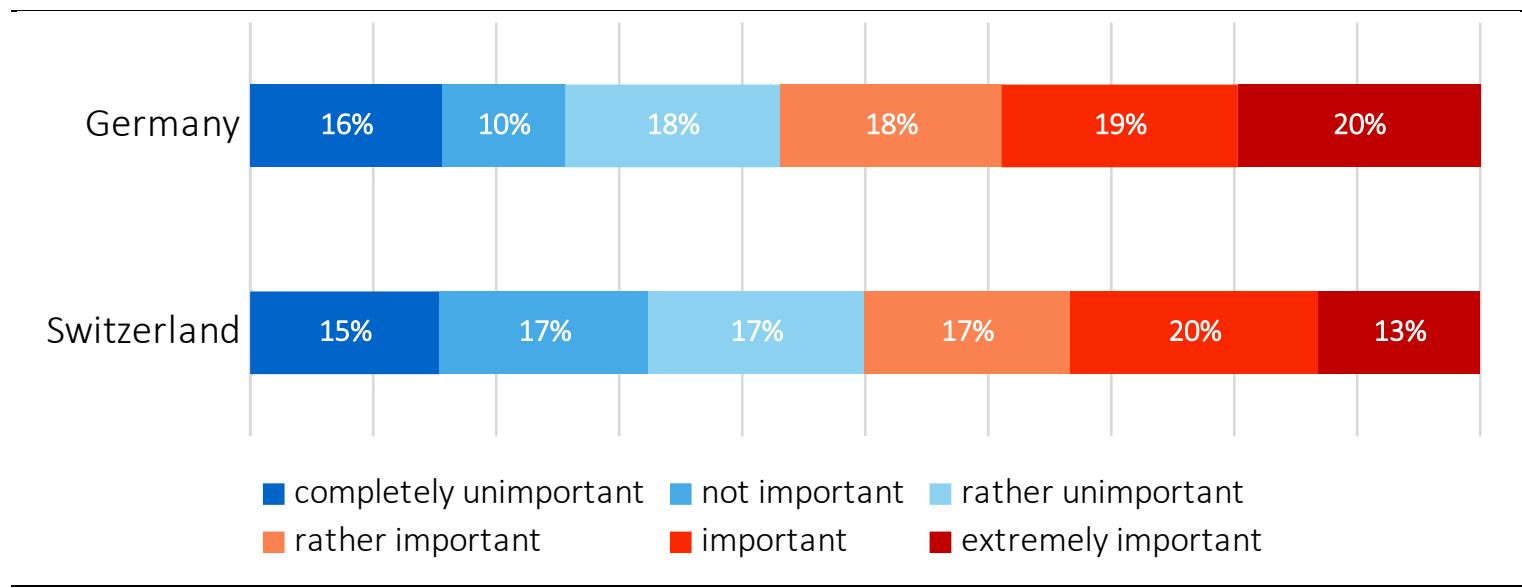

Source: KONID Survey DE and CH 2019/ Figure: KONID-Team (all percentages rounded; sums may deviate from 100)

The KONID Survey 2019 uncovers the current relevance of such social identities based on religion (Fig. 3.1). ${ }^{10}$ Respondents were asked about the importance for their own identity of their specific affiliation to a particular religion or of their non-affiliation to any religion at all. They could specify their answer on a six-point scale from "completely unimportant" to "extremely important". ${ }^{11}$ The wording of the questionnaire aimed at the respondent's concrete religious tradition and affiliation, i.e., how important it is for her or him to "be a Christian" or to "be a Muslim", etc. Firstly, the survey addressed the most common religious traditions: Christian, Jew, Muslim, Buddhist, Hindu, other religions, and the category of those who "do not belong to a religion". A second question specified a particular affiliation. It asked for the importance of the respondent's specific denomination or orientation within the respective religious tradition. In the following, for the sake of simplicity, we refer to this second variable as "denomination". In contrast to the first question about the importance of the social identity "religion", the latter question was understandably not presented in that form to those without a religious affiliation. However, they were questioned about the different dimensions of their religiosity, too. 
In Germany, the social identity "religion" is important to $57 \%$ of the population. Hence, more than half of the population consider religious affiliation, or the lack thereof, to be important for their self-perception. In Switzerland, 50\% of the population also name religion as being personally important as a social identity. These key data for both countries are calculated as the sum of "rather important", "important" and "extremely important". Moreover, it is instructive to compare the answers according to these three gradations. In Germany, religion as a social identity is "important" for $19 \%$, and "extremely important" for about $20 \%$ of the population. Things are somewhat different in Switzerland. While in Switzerland the figures for "rather important" (17\%) and "important" $(20 \%)$ hardly differ from Germany, there is a noticeable difference for "extremely important": at $13 \%$, the answer "extremely important" is much less frequent than in Germany, where one in five people rate religion as "extremely important".

At the other end of the response scale, the proportions are almost equal for the category of strongest rejection. In Germany and Switzerland, about 15\% consider religious affiliation to be a "completely unimportant" social identity for themselves. Significantly more respondents in Switzerland (17\%) than in Germany (10\%) rate this social identity as "unimportant". Since the value of the moderate category of rejection, "rather unimportant", is not higher than in Germany (both around $18 \%$ ), it is evident that overall the Swiss respondents are more resolute in their rejection of religious affiliation as a social identity than their German neighbours.

In sum, this basic comparison yields a threefold conclusion. (1) For many people, religious affiliation, as defined above, is important as a social identity. Combined, the categories "important" and "extremely important" account for almost 33\% in Switzerland, i.e. one third, and for even about $40 \%$ in Germany. In the context of broad debates on secularisation and the prevailing opinion that religion and religiosity no longer belong in the public sphere, this finding is very significant. (2) It is also striking that religion as a social identity meets both strong approval and strong rejection. The fact that the two ends of the answer scale are heavily populated, while the vaguer middle categories are not, signals that religion as a social identity is potentially controversial in both democratic societies. Some people emphasise the importance of their religious affiliation (or non-affiliation) for their identity, while others reject religion as a part of their social identity. This finding will become important again later. (3) Finally, there is a certain difference between Germany and Switzerland. Although the pattern of distribution is similar, the exact percentages reveal that the social identity "religion" is slightly more important for respondents in Germany than in Switzerland.

This basic finding will be differentiated further in the following. From now on, for the sake of simplicity, when we use the term "social identity 'religion'", we address the self-positioning of respondents regarding the importance of their religious affiliation (or non-affiliation) as a social identity. The concept of religious affiliation as formal belonging or membership and the concept of religiosity as the respondent's personal expression of religion and faith must be clearly distinguished from the "social identity 'religion'". In the analysis to follow, all three variables are used as conceptually different variables.

The starting question, then, is whether religion as social identity is actually a social factor in its own right. If that were the case, religious social identity could become a relevant factor in other contexts like civil society and politics. Yet, it might also be the case that the social identity 'religion' is just another expression of formal religious affiliation and/or personal religiosity. The following data show that there are some correlations among the three variables. However, these are not so strong that one could speak of them as expressions of an underlying general construct that was only measured differently. The social identity 'religion' is indeed a social fact in its own right. That we can nevertheless observe certain links should not be surprising. After all, it is plausible to assume that 
there are some positive links between a person's religious social identity, her or his formal membership of a religion, and, above all, her or his religiosity.

If we differentiate the social identity 'religion' according to the most commonly known religious traditions, including the group of persons without a religious affiliation, considerable differences become apparent. This is true for both Germany and Switzerland (Figs. 3.2 and 3.3).

Figure 3.2: Importance of the Social Identity 'Religion' by Religious Affiliation in Germany

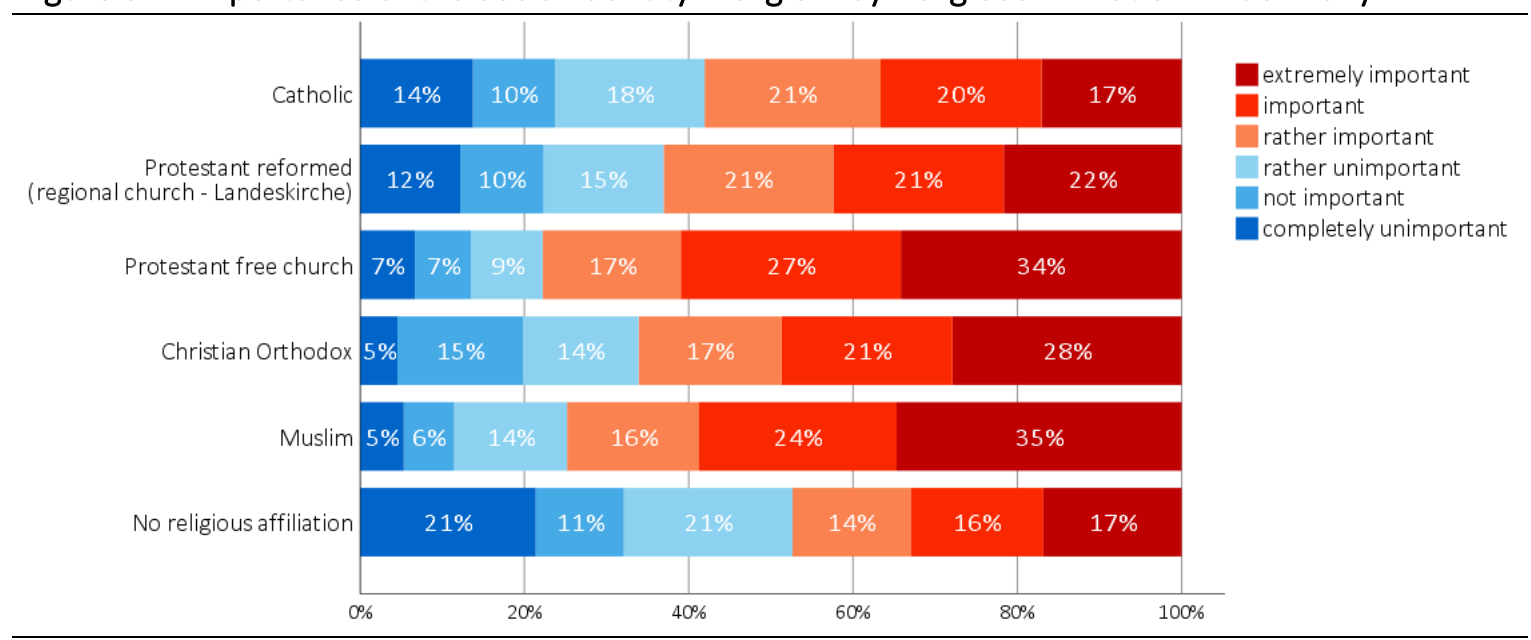

Source: KONID Survey DE 2019 / Figure: KONID-Team

Figure 3.3: Importance of the Social Identity 'Religion' by Religious Affiliation in Switzerland

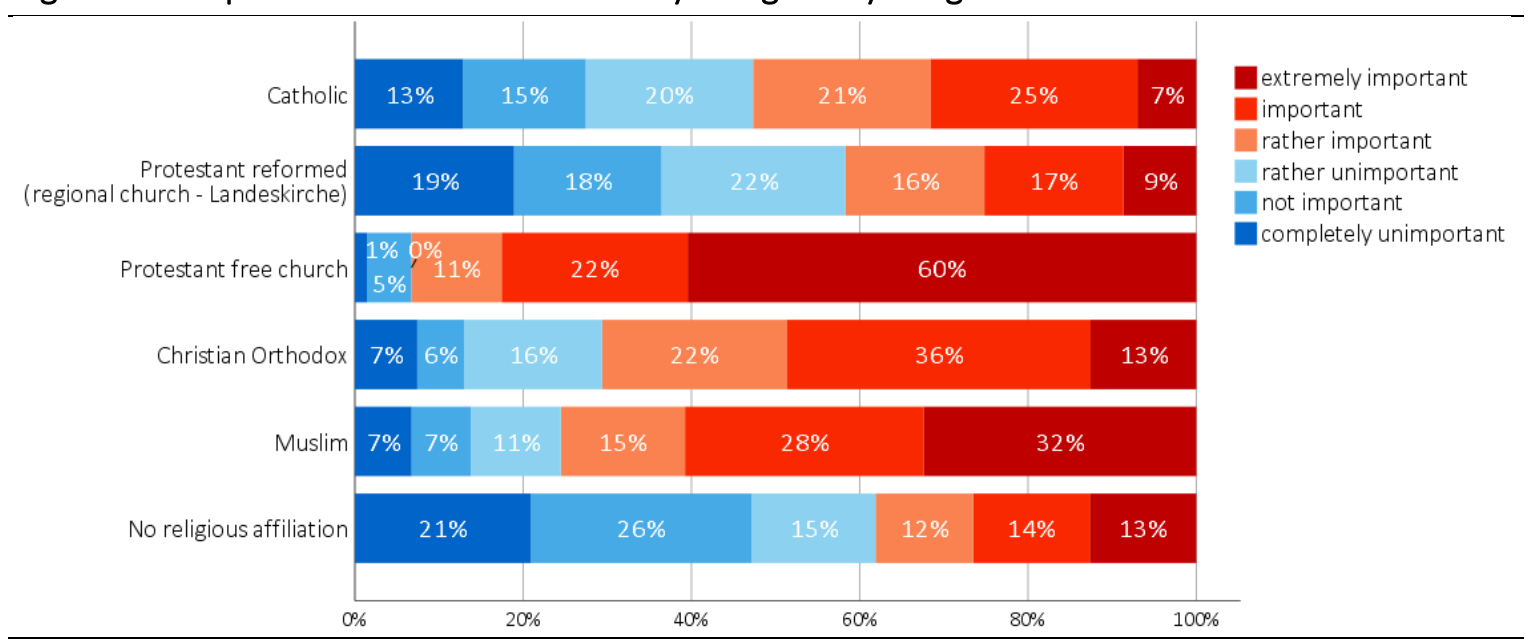

Source: KONID Survey CH 2019 /Figure: KONID-Team

In Germany, the social identity 'religion' is particularly important for members of Protestant free churches, with $61 \%$ considering their religious social identity to be "important" or "extremely important" (27 and 34\%). Similarly, 59\% of the Muslim respondents deem it important or very important (24 and 35\%). Among Orthodox Christians, the same applies to 49\%; among the mainline Protestants, to $43 \%$; and among members of the Catholic Church, to $37 \%$. For $33 \%$ of those without any religious affiliation, the fact of not belonging to a religion is an important expression of their social identity, too.

The picture is similar in Switzerland, but it is even more pronounced in terms of differences in proportions. Again, the greatest importance is found (by far) among members of Protestant free churches at $82 \%$. They ascribe great importance for their personal identity to their church 
membership. Only very few members of free churches consider their religious social identity to be unimportant. The situation among members of Muslim communities is quite similar, although the percentage is somewhat lower. $60 \%$ of Muslims name religion as a social identity that is important to them. Among Orthodox Christians, the same applies to 49\%; among Catholics, to 31\%; and among the reformed Protestants ("Landeskirchen"), to $26 \%$. A clear majority of those belonging to the Protestant reformed church deem their religion, i.e. being a Christian, to be an unimportant social identity, with almost 60\% choosing "rather unimportant", "not important", or "completely unimportant" as their answer. Their repudiation hardly differs from the percentage distribution among those without a religious affiliation. However, it is noteworthy that in the latter group, which is quite large in both countries, $27 \%$ regard their non-affiliation to be an important social identity for themselves.

Table 3.1a: Religious Affiliation of Respondents

\begin{tabular}{lcc}
\hline & Germany & Switzerland \\
\cline { 2 - 3 } Catholic & $26.1 \%$ & $36.5 \%$ \\
Protestant (mainline) & $25.1 \%$ & $23.7 \%$ \\
Protestant free church & $4.3 \%$ & $2.5 \%$ \\
Christian Orthodo** & $1.1 \%$ & $2.6 \%$ \\
Other Christian church or community* & $0.9 \%$ & $2.0 \%$ \\
Judaism* & $0.1 \%$ & $0.4 \%$ \\
Islam & $1.6 \%$ & $4.9 \%$ \\
Buddhism* & $0.4 \%$ & $0.6 \%$ \\
Hinduism* & $0.1 \%$ & $0.3 \%$ \\
Other religious community* & $0.7 \%$ & $0.8 \%$ \\
No religious affiliation & $39.7 \%$ & $25.8 \%$ \\
\hline
\end{tabular}

Note: * The estimates for these groups are based on fewer than 50 observations, with the exception of the Christian Orthodox in Switzerland. Both the estimates here and their data in the following should therefore be interpreted with great caution for these groups. The low proportion of Muslims in Germany results from the specific sample design and the well-known problem that minorities are often under-represented in surveys. Estimates by the "Swiss Metadatabase of Religious Affiliation in Europe (SMRE)" assume 5\% for Germany (www.smre-data.ch).

Source: KONID Survey DE and CH 2019 / Table: KONID-Team

Contrasting these findings with the KONID results for religious affiliation in both countries and the size of the respective religious communities (Tab. $3.1 \mathrm{a}$ and b), we can see that religious social identity is much more important among religious minorities than among those who belong to traditional mainstream churches.

Table 3.1b: Persuasions and Schools within Islam

\begin{tabular}{lcc}
\hline & & \\
& & \\
\cline { 2 - 3 } Sunnites & $73.5 \%$ & Switzerland \\
Shiites* & $5.6 \%$ & $77.8 \%$ \\
Alevi* & $9.8 \%$ & $3.2 \%$ \\
Ahmadiyy* & $1.4 \%$ & $2.5 \%$ \\
Other Muslim schools* & $3.3 \%$ & $0.5 \%$ \\
No specific persuasion or school* & $6.5 \%$ & $3.7 \%$ \\
\hline
\end{tabular}

Note: * The estimates for these groups are based on fewer than 50 observations. Both the estimates here and in the following should therefore be interpreted with great caution.

Source: KONID Surveys DE and CH 2019 / Table: KONID-Team 
Against the backdrop of current public debates on religion and Islam in particular, the following fact is noteworthy: neither immigration nor "Islam" is necessarily pivotal as such. In fact, the high importance of religious social identity was observed among religious minorities in general. The Christian free church segment in Germany and Switzerland has a long tradition, which partly goes back to the time of the early Reformation. Like Muslim respondents, its members tend to rate their religious social identity as "important" or "extremely important". This "minority-effect" is even more pronounced in Switzerland than in Germany. This result of a general minority effect is interesting with regard to the public discourse on the "special role of Islam in society". Identification with one's religious group is very strong not only among Muslims, but also among other religious minorities. One possible explanation could be that the social identity 'religion' takes on greater importance in smaller religious communities due to their more dogmatic understanding of faith.

It is worth looking at the two large churches. For the Catholic Church, the values in both countries are similar and they are rather low. This low level of identification is possibly related to the series of church scandals in recent years and to the longstanding non-responsiveness of the church hierarchy to the wishes of church members, especially of women, to see change and increased participation. If we look at the Protestant mainline churches, it is difficult to explain the apparent difference between the Protestants in Germany and the Reformed Christians in Switzerland. In Switzerland, their identification is particularly low. This low importance of religious identity among the Swiss Reformed requires an explanation. If participation in decision-making processes matters for religious identification, the figures should be higher: built along the same lines as the political system, the regional churches in Switzerland are familiar with strong and direct democratic involvement in church bodies, at both the local and cantonal level. The low level of identification of Protestant church members with their religion as social identity is striking and needs further attention.

For a better understanding of the social identity 'religion', it is worth examining the results for the social identities 'religion' and 'denomination' comparatively (Tab. 3.2). This differentiation allows us to discuss internal differences within the religious traditions. The comparison reveals that religion as a social identity is generally less oriented to the specific denomination or religious group of a respondent, but more often shaped by the broader religious categories "Christian", "Muslim" or "no religious affiliation". For the sake of clarity, we report here only the sums of the two response categories at the respective ends of our 6-point scale. The decisive finding is that the same pattern occurs across all Christian denominations and for Sunni Islam: on average, the generic categories "Christian" and "Muslim" are more important to respondents than the specific denomination or school of faith. This difference is particularly striking among the mainline Protestants in Switzerland, more than $40 \%$ of whom consider their denomination to be unimportant or completely unimportant as a social identity. Furthermore, with a certain reservation due to the smaller numbers of observations, we want to draw attention to a special effect within Islam. Shiite respondents attach greater importance to their specific religious school of faith than to their general affiliation to Islam. This effect is even stronger among Alevis, who are systematically disadvantaged in Turkey, their main country of origin. Within the Alevi community in Switzerland, there seems to be a clear rejection of the idea of belonging to Islam. In Germany, this demarcation is not so strong, but here too the social identity of a person's specific religious belonging predominates among Alevis. ${ }^{12}$

In modern democratic societies, a person's religiosity is more helpful to understand religion and its correlates than the mere fact of her or his formal religious or denominational affiliation. The KONID Survey contains numerous variables referring to religious behaviour and religious belief that can be used to measure individual religiosity. A scientifically validated way to combine this variety of 
variables in a meaningful way is the Centrality of Religiosity Scale (CRS). The CRS has been designed to measure individual religiosity consistently by looking at six dimensions of religion. ${ }^{13}$ On the basis of this standardised scale, we can distinguish three groups with very different levels of religiosity: the "highly religious", the "religious", and the "non-religious". ${ }^{14}$ In Germany, according to this scale and our data, $15 \%$ are highly religious, $49 \%$ are religious, and $36 \%$ are non-religious. In Switzerland, the percentages shift somewhat in the direction of being more religious: $19 \%$ are highly religious, $55 \%$ are religious, and $26 \%$ are not religious at all.

Table 3.2: Importance of the Social Identities "Religion" and "Denomination" by Traditions and Denominations

\begin{tabular}{|c|c|c|c|c|c|}
\hline \multirow[b]{2}{*}{$\begin{array}{l}\text { Religion / Denomina- } \\
\text { tion or School }\end{array}$} & \multirow[b]{2}{*}{ Social identity } & \multicolumn{2}{|c|}{ Germany } & \multicolumn{2}{|c|}{ Switzerland } \\
\hline & & $\begin{array}{c}\text { not } \\
\text { important / } \\
\text { completely } \\
\text { un- } \\
\text { important }\end{array}$ & $\begin{array}{l}\text { important } \\
/ \\
\text { extremely } \\
\text { important }\end{array}$ & $\begin{array}{c}\text { not } \\
\text { important/ } \\
\text { completely } \\
\text { un- } \\
\text { important }\end{array}$ & $\begin{array}{c}\text { important } \\
/ \\
\text { extremely } \\
\text { important }\end{array}$ \\
\hline \multicolumn{6}{|l|}{ Christianity } \\
\hline Christians in general & Christian & $22 \%$ & $41 \%$ & $29 \%$ & $33 \%$ \\
\hline \multirow[t]{2}{*}{ Catholic } & Christian & $24 \%$ & $37 \%$ & $27 \%$ & $32 \%$ \\
\hline & Catholic & $28 \%$ & $30 \%$ & $34 \%$ & $27 \%$ \\
\hline \multirow[t]{2}{*}{ Prot. (mainline) } & Christian & $22 \%$ & $42 \%$ & $37 \%$ & $25 \%$ \\
\hline & Protestant ref. & $25 \%$ & $34 \%$ & $42 \%$ & $16 \%$ \\
\hline \multirow[t]{2}{*}{ Prot. free church } & Christian & $14 \%$ & $61 \%$ & $7 \%$ & $83 \%$ \\
\hline & Prot. Free Church & $23 \%$ & $42 \%$ & $12 \%$ & $68 \%$ \\
\hline \multirow[t]{2}{*}{ Christian Orthodox } & Christian & $20 \%$ & $49 \%$ & $13 \%$ & $49 \%$ \\
\hline & Christian Orthodox & $16 \%$ & $53 \%$ & $20 \%$ & $49 \%$ \\
\hline \multicolumn{6}{|l|}{ Islam } \\
\hline Muslims in general & Muslim & $11 \%$ & $59 \%$ & $14 \%$ & $61 \%$ \\
\hline \multirow[t]{2}{*}{ Sunnites } & Muslim & $10 \%$ & $64 \%$ & $15 \%$ & $60 \%$ \\
\hline & Sunni & $14 \%$ & $51 \%$ & $23 \%$ & $37 \%$ \\
\hline \multirow[t]{2}{*}{ Shiites } & Muslim & $13 \%$ & $58 \%$ & $5 \%$ & $30 \%$ \\
\hline & Shiite & $24 \%$ & $39 \%$ & $7 \%$ & $33 \%$ \\
\hline \multirow[t]{2}{*}{ Alevi } & Muslim & $26 \%$ & $38 \%$ & $53 \%$ & $7 \%$ \\
\hline & Alevi & $15 \%$ & $51 \%$ & $17 \%$ & $75 \%$ \\
\hline $\begin{array}{l}\text { No religious } \\
\text { affiliation }\end{array}$ & no member of rel & $32 \%$ & $33 \%$ & $47 \%$ & $27 \%$ \\
\hline
\end{tabular}

Source: KONID Surveys DE and CH 2019 / Table: KONID-Team

To compare the relevance of religion as a social identity along with these three categories of religiosity more accurately, we need to distinguish between those who do and those who do not belong to a religious community. The separate study of people without a religious affiliation follows recent research approaches. ${ }^{15}$ It is important to note, the latter category - often referred to as the "nones" - is still a rather generic category, because it includes rather different traditions and groups like atheists, agnostics, pagans, or just religiously indifferent people. 
Figure 3.4: Importance of the Social Identity 'Religion' Among People with a Religious Affiliation According to Religiosity in Germany

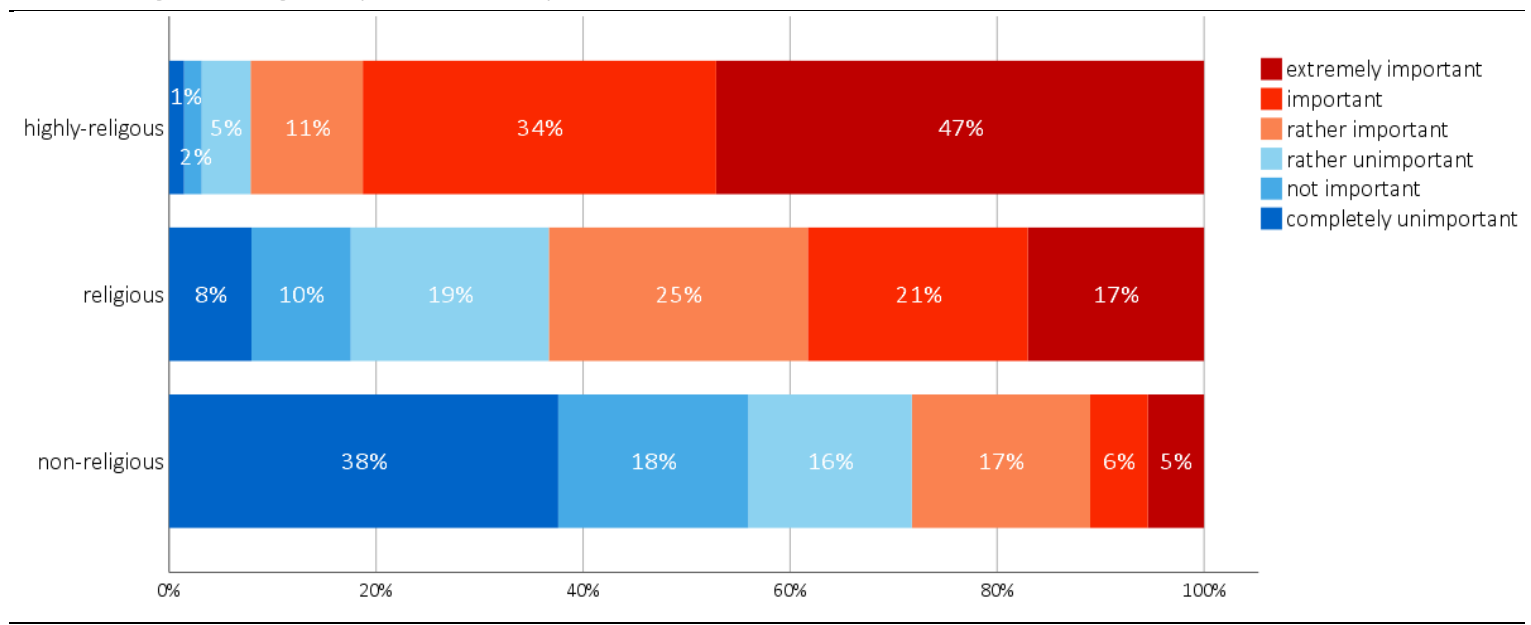

Source: KONID Survey DE 2019 / Figure: KONID-Team

Figure 3.5: Importance of the Social Identity 'Religion' Among People with a Religious Affiliation According to Religiosity in Switzerland

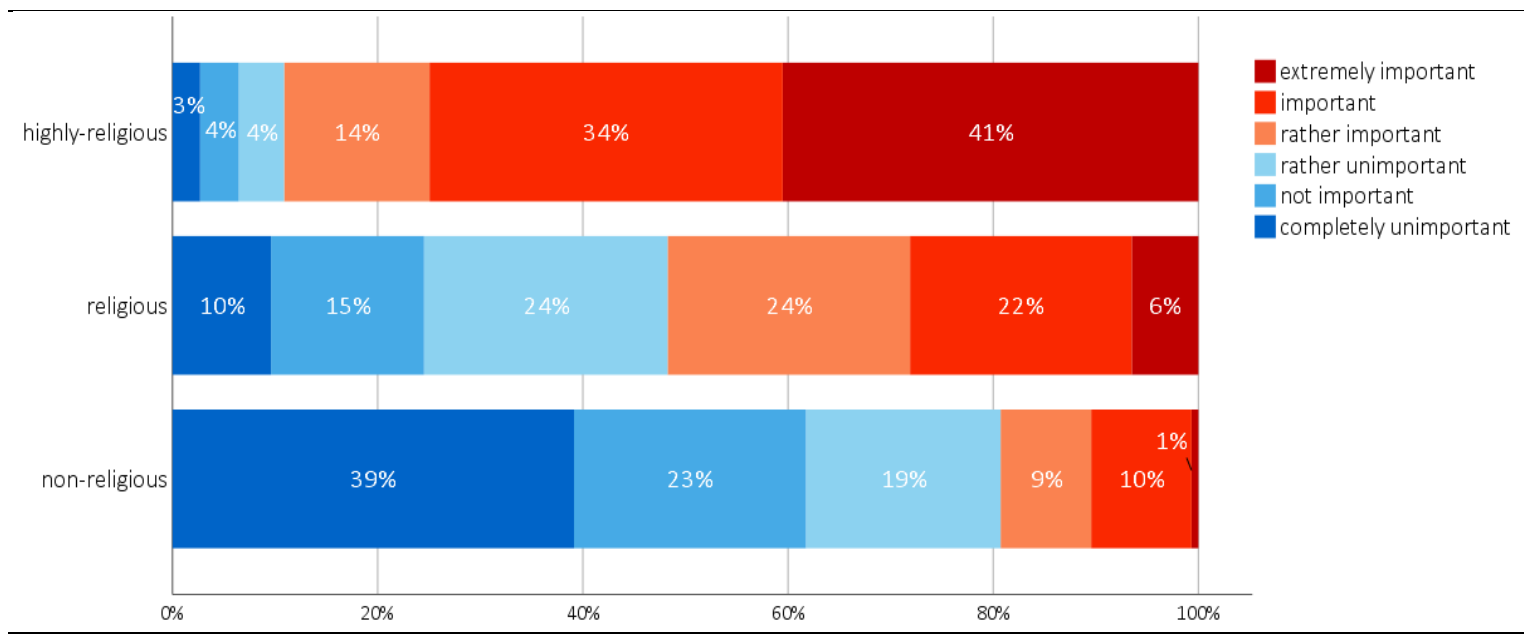

Source: KONID Survey CH 2019 / Figure: KONID-Team

If we first look at those who reported a formal religious affiliation (Figs. 3.4 and 3.5), the following becomes apparent: unsurprisingly, the highly religious also attach very high importance to their religious social identity. In both countries, a large majority of those who are highly religious describe their social identity 'religion' as "important" or "extremely important" (over 80\% in Germany, over $75 \%$ in Switzerland). For the non-religious who belong formally to a religious community, the situation is - as one can expect - the reverse. Here, the social identity 'religion' is unimportant for most respondents. This connection is even more pronounced in Switzerland than in Germany. This finding is consistent with the results described above. However, regarding the middle category "religious", which in both countries forms the largest group on the CRS, it becomes evident that social identity and religiosity are not systematically linked. In this group, the respondents are distributed across all six levels of importance of the social identity 'religion'. Finally, concerning this middle group, the two extreme ends of the identity scale and the less committed categories "rather important" and "rather unimportant" are roughly in balance. In Switzerland, this is clearly the case. In Germany, persons classified as religious tend to cite religion as being important for their social identity slightly more frequently. This finding also sheds some light on the question of why the values for religious identity are overall somewhat higher in Germany: comparatively, religious 
identity matters more to those categorised as religious in Germany. On aggregate, this gives more weight to the upper end of the social identity scale.

In both countries, $11 \%$ of the group of non-religious that named a religious affiliation state that the social identity 'religion' is "important" or even "extremely important" to them. What does this interesting combination mean? We are probably facing here a more recent phenomenon in the history of religion. In today's rather secularised societies, there are people who were baptised and kept their affiliation later on, but who do not have any practical or content-related contact with their religion in everyday life. Our data indicate that some of these, nonetheless, regard their purely formal membership as an important point of reference for understanding their social identity.

Since this phenomenon mainly affects the large Christian churches, this group can perhaps best be described as "non-religious cultural Christians". It is conceivable that the emergence of this group reflects the increasingly sharp demarcation between the categories "Christianity" and "Islam" in public discourse. Presumably, there is a new mechanism at work: namely, these "non-religious cultural Christians" try to counter the suspected "Islamisation" of their society by ostentatiously asserting the cultural heritage of Christianity and the "Christian Occident" or "Christian-Jewish Occident". In terms of content, they do not connect this assertion with the Christian faith as such. This mechanism corresponds to the exclusionary logic of in-group and out-group dynamics to upgrade one's group status and, thus, social identity, as Social Identity Theory postulates. The positive reference to one's group serves as a distinguishing feature to improve one's self-esteem by comparing it with those declared to be "others", "strangers", or "enemies".

Independent of whether the explanation offered here can be substantiated in further research, the KONID Survey provides empirical evidence that such a new group of "non-religious cultural Christians" actually exists in Germany as well as in Switzerland. In this group, religion is all about selfidentification despite the lack of personal religiosity. Such empirical evidence did not exist until now. To allude to the well-known book "Believing without belonging" in the sociology of religion, one could speak of "identifying without believing". ${ }^{16}$ It is difficult to determine the exact proportion of this group within the population, since there are probably fluid transitions between the nonreligious and the religious when it comes to "identifying without believing". According to our estimates, its proportion is probably a little under $10 \%$ in both countries.

Similar fluid transitions or effects of fuzziness are also likely between the highly-religious group and those persons categorised as religious that show somewhat higher values on the CRS than the rest of the religious. In both groups of religiosity, certain proportions of its members rate their social identity 'religion' as unimportant or completely unimportant. The data thus also provide an empirical indication of "believing without belonging", i.e. here a believing without identifying with one's religious affiliation as a social category.

Since the CRS measures the respondents' religiosity independently of any religious affiliation or membership, people with different degrees of religiosity may also be among those without any religious affiliation. Indeed, this is empirically the case in both countries (Figs. 3.6 and 3.7). Among people in this category, often wrongly called "without religion", are some who are de facto religious or even highly religious. In contrast to those with a religious affiliation, the position on the CRS and the evaluation of the social identity 'religion' of the group without a religious affiliation do not correlate statistically. ${ }^{17}$ As expected, the largest subgroup among people without a religious affiliation is comprised of the non-religious. The KONID data show that an astonishing 38\% (Germany) and $31 \%$ (Switzerland) consider the fact of their non-affiliation to be an important social identity. In this data, we can see the potential of those "nones", who reject religion on principle. 
Figure 3.6: Importance of Social Identity 'Religion' Among People Without a Religious Affiliation According to Religiosity in Germany

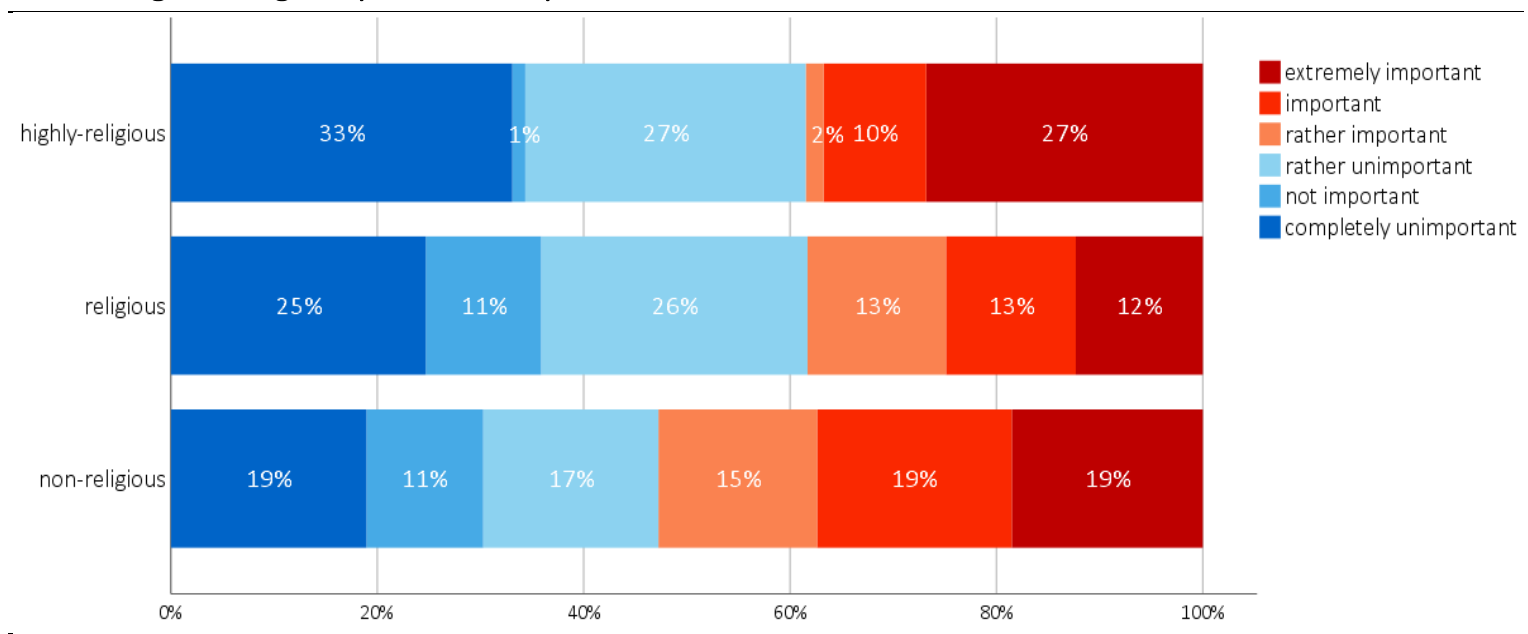

Source: KONID Survey DE 2019 / Figure: KONID-Team

Figure 3.7: Importance of Social Identity 'Religion' Among People Without a Religious Affiliation According to Religiosity in Switzerland

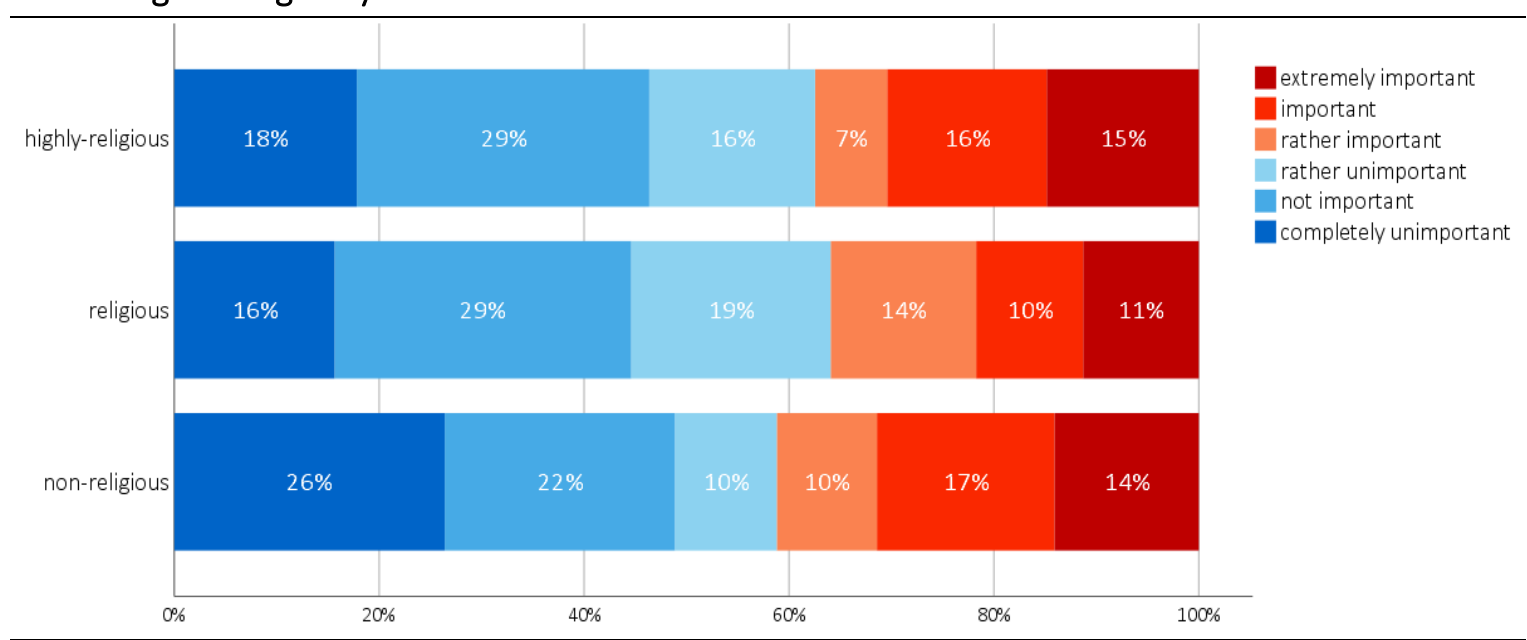

Source: KONID Survey CH 2019 / Figure: KONID-Team

There is also the opposite case among those without a religious affiliation: namely, there are some people who are religious or highly religious and consider their social identity 'religion' hence here i.e. "not belonging to any religion" - to be important or extremely important. Where does their identification with the social identity of having 'no religion' come from? This subgroup consists of people who have turned away from institutional or organisational forms of religion, or who never considered them, but who view their personal religiosity as being very important. Among them might be those who are enthusiastic about alternative spiritual or esoteric religious practices and ideas. ${ }^{18}$ 


\section{Religious identity in the context of social identities}

A person has many social roles and social affiliations. This diversity ultimately determines the respective social identity. Social roles and affiliations are partly self-determined and freely chosen, partly the result of socialisation and life stories, and partly caused by external circumstances and constraints of groups and society. ${ }^{19}$ In chapter 7 , we will show which patterns of social identities are identifiable within the great diversity of people and how these patterns can be described.

First, we will discuss the multitude of social identities. Then, the social identities 'religion' and 'denomination' will be contextualised within this universe of identities. In Germany as well as in Switzerland, many of the 21 social identities covered by the KONID Survey are of high importance (Fig. 4.1). Nevertheless, not all social identities are equally important. A country comparison, where the answer options "important" and "extremely important" are combined into "important", shows that the two countries are generally similar in terms of the importance of the different social identities and their gradations. Almost all social identities are considered important somewhat more often in Germany than in Switzerland. This could be an expression of the fact that the Swiss economy and with it the welfare state are comparatively individualistic. ${ }^{20}$ Only the social identity 'nationality' is rated higher by respondents in Switzerland than by respondents in Germany. The lower importance of nationality is a consequence of German history during the Nazi era. The reported effect of distancing oneself from the nation is well known from other surveys. ${ }^{21}$

One's family affiliation and membership of a circle of friends are by far the most important social identities. The family has a high level of importance for more than $80 \%$ of respondents, and the circle of friends is of high importance for almost $70 \%$. This social identity is not important at all for only very few people. Family and friends are followed by marital status. Besides being single, separated or widowed, this mainly includes the family roles of wife/husband and mother/father. This is followed by - if relevant - voluntary work. This finding underlines the strong importance of civil society for the individual, insofar as she or he is part of its activities. This top-four group of social identities is followed by a midfield comprising the social identities gender, profession, nationality, being European, age group, and country of birth. In terms of importance, they reach values of between 40 and $52 \%$ in both countries. Other social identities are less important. Following at a small distance are political orientation and then religion. Social class and denomination - both key identities of classical modernity - are at the lower end of the importance scale. Also noteworthy is the very low importance of the federal state or canton of residence. Clearly more important to the respondents is their own area of origin, whether this is within or outside the two countries. At the end of the scale is the feeling of belonging to the fan community of a sports club. For three quarters of respondents, this social identity is rather unimportant.

It is important to take a second look at the data on self-identification with the 21 social identities. In addition to the question of their importance among the population, it is also relevant whether and, if so, to what extent - they are assessed differently in each case. This can be statistically determined by looking at the distribution of the answers across the six levels of importance. If the two poles of the scale are strongly populated, the variance is high. This might indicate that a social identity is socially controversial. Some members of society consider these social identities to be particularly important for their own social identity, while others strictly reject them for themselves. Indeed, empirically, there exist some of these polarising social identities which receive simultaneously high approval and strong rejection rates. In the top-four group, this applies to marital status. It is for many people extremely important or important. However, there is also a strong minority 
that strongly reject this identification. This effect also occurs in the case of the social identity 'religion'. The fact that religious affiliation tends to be one of the less important social identities is due to the fact that the two poles of the importance-scale are heavily populated while the middle categories are chosen less frequently (see Fig. 3.1 above). The same applies to 'denomination'. For Germany in particular, there is another polarising variable which represents a rather conflictual social identity: the importance of belonging to East or West Germany. Here, too, the two ends of the scale are heavily populated.

Two things can be concluded from this first contextualisation of the social identity 'religion'. Firstly, the religious and especially the denominational identity are of comparatively low importance for the majority of respondents, and thus for the population as a whole. Many other social identities are more often considered important. Secondly, religion and denomination nonetheless count amongst the social identities that the respondents evaluate very differently. On the one hand, for quite a few people, their affiliation to a religious group creates a high degree of cohesion and strongly shapes their self-image of social identity. On the other hand, there is also a group of respondents who sharply reject religion and denomination as a social identity. The effects of this double finding on the social level will become apparent at the end of the report, where the social identities presented here are examined in terms of configurations of social identities in general. 

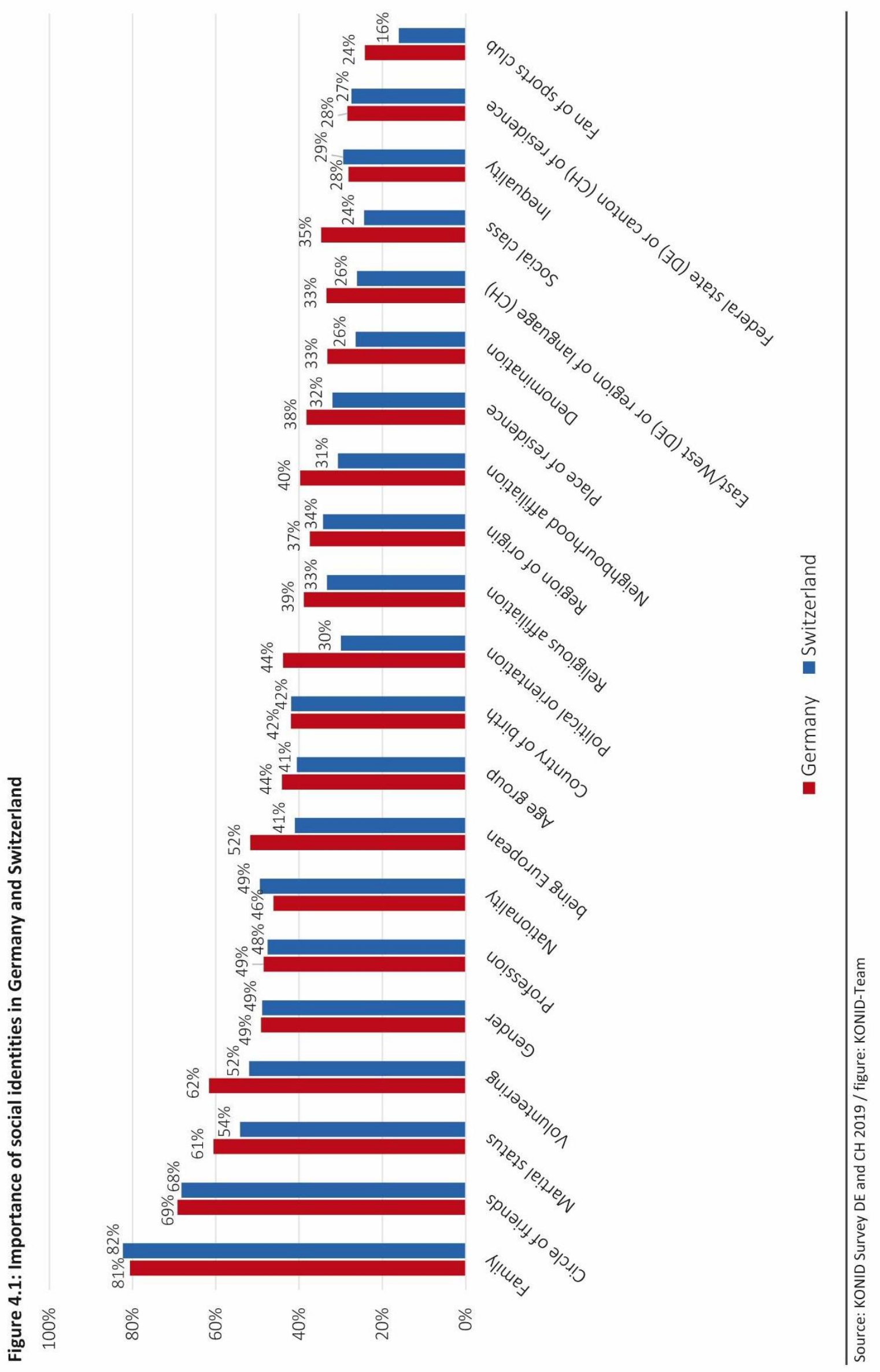


\section{Religious identities and social divisions}

The potentially conflictual nature of the social identity 'religion' requires us to examine how strongly religious identities and beliefs divide and polarise society. Roughly speaking, such divisive effects of social identity can have two starting points. On the one hand, they can be based on the respondent and her or his group bonding. A high appreciation for one's own in-group does not necessarily have to lead to separation from the out-group. Nevertheless, it can be an instrument to present and experience oneself as "being better" than others. If the high appreciation for one's social identity is accompanied by a devaluation of other groups, then this will lead to discrimination against and exclusion of the out-groups. According to Social Identity Theory, the desire for high self-esteem becomes the driving force behind potentially problematic group comparisons. The in-group seeks to prove its superiority by presenting out-groups as inferior and by excluding them. ${ }^{22}$

In contrast, the effect can also occur quite independently of the intention and behaviour of the respondents. In this case, the attribution of the conflict comes from the outside and casts one's social identity in a completely different light. For the example of religious affiliation, this means that one has to adopt a new attitude towards the previously more or less unquestioned normality of "being a Christian" or "being a Muslim". Whenever religious affiliations are successfully used as a marker of social boundaries, this external pressure on those who are affected arises. Possible counter-reactions are: deliberate rejection of the ascribed social category as part of one's social identity; demarcation and bonding within one's group to stabilise self-esteem; or mobilisation of counterforces to carry out the conflict. The latter option is only available to larger groups or groups with a higher social status.

To approach this problem empirically, we should first compare the importance of the social identity 'religion' for the individual with how it is evaluated by her or his immediate social environment. The KONID Survey explored how respondents perceive the expectations of their closest social environment, with the survey question being: "When you think of other people close to you and how they appreciate you, which of your characteristics do they value?"

A comparison of the percentages for the individual importance of social identity ("important" and "extremely important") and the perceived appreciation of this identity by others ("appreciated or valued" and "extremely well appreciated or valued") allows us to assess the social embeddedness of religious identity (Tab. 5.1). For Christians, Muslims, and people without any religious affiliation in both countries, it is striking that the figures for their personally stated importance are almost throughout much higher than for the appreciation by the relevant social environment (all other categories are excluded from this analysis due to the low number of observations). This discrepancy can be interpreted in two ways. Its meaning probably depends very much on the size of the gap between personal importance and external appreciation of a given social identity. First of all, it is probably an expression of the everyday experience of individuals with any social identity in plural societies ${ }^{23}$ : the individual is usually not (primarily) forced into a social identity by strong external group pressure. While there is some support for one's social identity 'religion' through appreciation by one's social environment, the importance of one's social identity is more strongly determined by individual preference. The statistical difference between importance and appreciation points to this identity work that has to be done by the individual. But what happens, second, if the gap becomes very large? Then the demand and importance of identity work of the individual increases substantially. This is because the individual must now represent and uphold its valued social identity 
in an environment that barely appreciates this identity or does not appreciate it at all, or that simply deems this identity insignificant.

Table 5.1: Importance and Appreciation of the Social Identities 'Religion' and 'Denomination'

\begin{tabular}{lcccc}
\hline & \multicolumn{2}{c}{ Germany } & \multicolumn{2}{c}{ Switzerland } \\
\cline { 2 - 5 } Social identity & & & & \\
\hline Christianity & Importance & Appreciation & Importance & Appreciation \\
$\quad$ Christian & $41 \%$ & $20 \%$ & $33 \%$ & $23 \%$ \\
$\quad$ Catholic & $30 \%$ & $15 \%$ & $27 \%$ & $19 \%$ \\
$\quad$ Protestant (mainline) & $34 \%$ & $17 \%$ & $16 \%$ & $15 \%$ \\
$\quad$ Protestant free church & $42 \%$ & $19 \%$ & $68 \%$ & $34 \%$ \\
$\quad$ Orthodox & $53 \%$ & $16 \%$ & $49 \%$ & $23 \%$ \\
Islam & & & & \\
$\quad$ Muslim & $59 \%$ & $29 \%$ & $61 \%$ & $38 \%$ \\
$\quad$ Sunni & $51 \%$ & $27 \%$ & $37 \%$ & $29 \%$ \\
$\quad$ Shiite & $39 \%$ & $30 \%$ & $33 \%$ & $33 \%$ \\
$\quad$ Alevi & $51 \%$ & $25 \%$ & $75 \%$ & $41 \%$ \\
No religious affiliation & & & & \\
$\quad$ not to belong to any religion & $33 \%$ & $9 \%$ & $27 \%$ & $15 \%$ \\
\hline
\end{tabular}

Source: KONID Survey DE and CH 2019 / Table: KONID-Team

In Switzerland, the difference between self-assessed importance and perceived external appreciation is rather moderate for most Christians (33 to 23\%). In contrast, there is a significantly weaker external appreciation in relation to the self-reported importance among Muslims (61 to 38\%) and those without any religious affiliation (27 to $15 \%$ ). At the level of denominations, it can be observed that for members of Protestant free churches and Shiites the situation differs from the overall picture. The former see their strong religious identity as being only supported a little by their surroundings (68 to 34\%). The situation is similar for the Orthodox Christians (49 to 23\%). In comparison to the general social identity 'Muslim', there are clearly fewer differences between the social identity 'Sunni' and 'Shiite' and their appreciation. This means that in this case the support from the social environment is stronger. Among Shiites, the role as a minority within the Muslim minority and a certain pressure to stick together within their own community could be relevant factors.

In Germany, the perceived social appreciation of one's social identity is consistently much weaker than in Switzerland. The personal importance tends to be twice as high as external appreciation. Those who do not belong to any religious community perceive an extremely low appreciation of this social identity (33 to 9\%). Orthodox Christians have a similarly low appreciation of their social identity 'religion' (53 to 16\%). Again, the comparison between Muslims and Christians is remarkable. In Germany and Switzerland, members of Muslim communities see a higher appreciation of their religious affiliation than their fellow Christian citizens. This finding is surprising at first sight, since both countries are culturally largely influenced by Christianity. Probably, it largely reflects an effect of the religious community as such. Compared to other religious groups, Muslims are more strongly anchored in their communities.

An important indicator of the divisive potential of religious identities is the experience of discrimination based on the respective identity. The KONID Survey measures discrimination on grounds of 
the social identity 'religion' by the following question: "Within the past 12 months, how often have you experienced prejudice or unfair treatment because of the following characteristics?" Respondents could reply with "never", "rarely", "often" or "very often". The results show that members of almost all religions and denominations report experiences of discrimination. This applies to both countries (Tab. 5.2). Therefore, the experience of discrimination is probably a fundamental part of living in plural societies. Nevertheless, this certainly does not justify such discrimination. In any case, no one is immune to it. However, the reported frequency (from "rarely" to "very often") varies according to religion and denomination. In Germany as in Switzerland, about one in five Christians and one in five people without any religious affiliation report at least some experiences of discrimination based on their social identity 'religion'. In stark contrast, one in two Muslims stated that they had been discriminated against due to their religious identity. The corresponding percentages for the different groups within Islam reveal that the experience of discrimination among Muslims results more from the general category "Muslim" than from the denominational groups. This corresponds to the familiar insight from empirical studies that in Germany as well as in Switzerland discrimination and exclusion with regard to Muslims is a matter of generalised categorisations, stereotyping, and exclusion based on attributing people to the religious affiliation "Muslim". ${ }^{24}$

Table 5.2: Experienced Discrimination Based on Social Identity 'Religion' or 'Denomination'

\begin{tabular}{|c|c|c|c|c|}
\hline \multirow[b]{2}{*}{ Social identity } & \multicolumn{2}{|c|}{ Germany } & \multicolumn{2}{|c|}{ Switzerland } \\
\hline & never & $\begin{array}{l}\text { rarely/often/ } \\
\text { very often }\end{array}$ & never & $\begin{array}{l}\text { rarely/often/ } \\
\text { very often }\end{array}$ \\
\hline \multicolumn{5}{|l|}{ Christianity } \\
\hline Christian & $81 \%$ & $19 \%$ & $83 \%$ & $17 \%$ \\
\hline Catholic & $78 \%$ & $22 \%$ & $83 \%$ & $17 \%$ \\
\hline Protestant (mainline) & $88 \%$ & $12 \%$ & $91 \%$ & $9 \%$ \\
\hline Protestant free church & $71 \%$ & $29 \%$ & $31 \%$ & $69 \%$ \\
\hline Orthodox & $53 \%$ & $48 \%$ & $66 \%$ & $34 \%$ \\
\hline \multicolumn{5}{|l|}{ Islam } \\
\hline Muslim & $51 \%$ & $50 \%$ & $44 \%$ & $56 \%$ \\
\hline Sunni & $71 \%$ & $29 \%$ & $69 \%$ & $31 \%$ \\
\hline Shiite & $62 \%$ & $38 \%$ & $31 \%$ & $69 \%$ \\
\hline Alevi & $67 \%$ & $33 \%$ & $76 \%$ & $24 \%$ \\
\hline \multicolumn{5}{|l|}{ No religious affiliation } \\
\hline not to belong to any religion & $80 \%$ & $20 \%$ & $81 \%$ & $19 \%$ \\
\hline
\end{tabular}

Source: KONID Survey DE and CH 2019 / Table: KONID-Team

The respondents with the least experience of discrimination based on their religious identity are members of the Protestant or Reformed churches (mainline churches). On the one hand, this is probably related to the low importance of religion as a social identity within this denomination. On the other hand, it might also be an expression of the former cultural dominance of the respective Protestant confession in both countries. ${ }^{25}$ In contrast to Germany, members of free churches in Switzerland very frequently report discrimination: $69 \%$ stated that they had experienced discrimination on the basis of their religious identity. This proportion is well above the already very high $56 \%$ for Muslims in Switzerland. In Germany, 48\% of Orthodox Christians report discrimination based on their religion. This level corresponds almost exactly to that among Muslims (50\%). Therefore, a general minority effect can be observed again. 
Figure 5.1: Frequency of Experiences of Discrimination in Germany

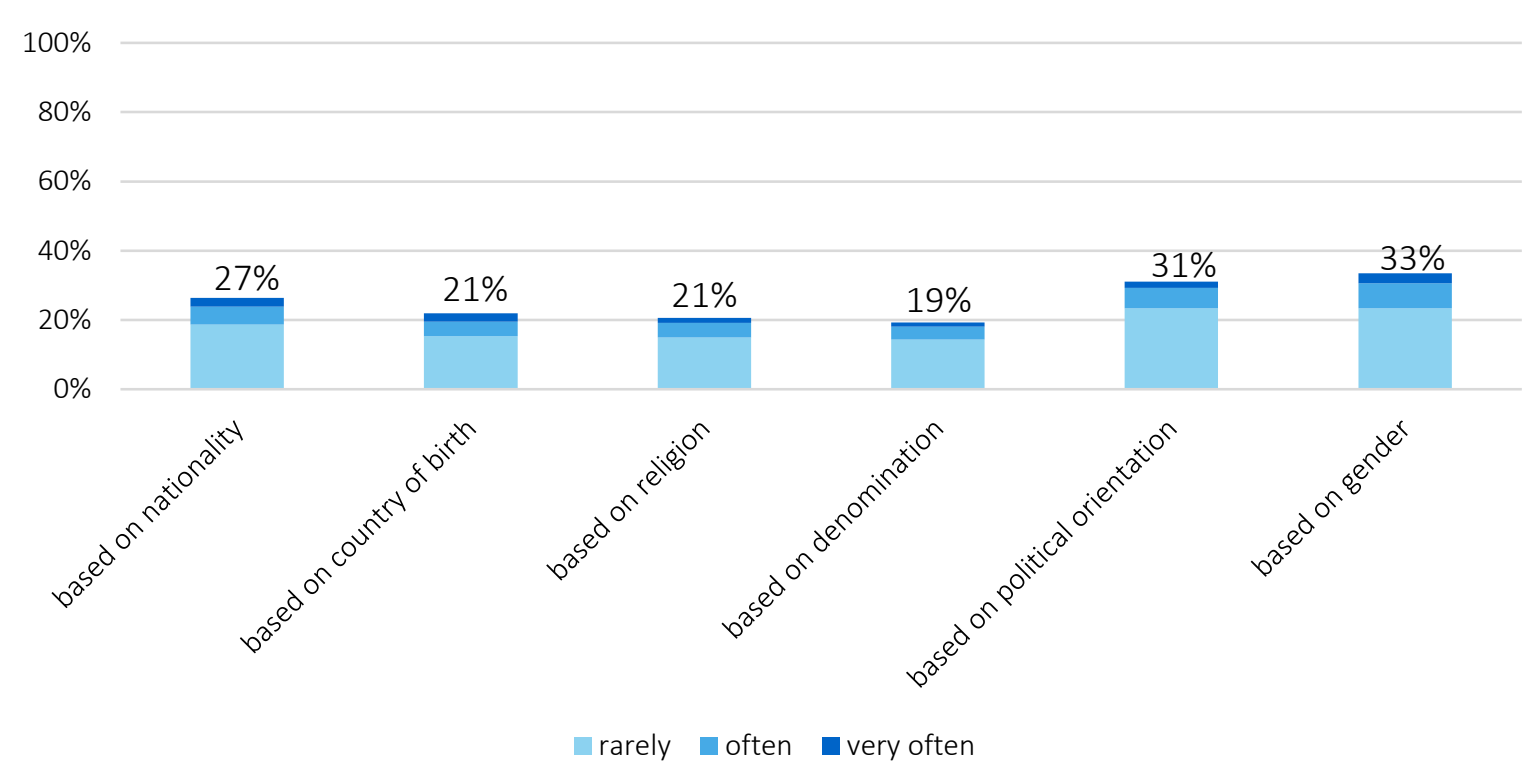

Note: The percentages are the sum of "rarely", "often" and "very often".

Source: KONID Survey DE 2019 / Figure: KONID-Team

This finding requires further contextualisation. So far, it may seem that discrimination is mainly about religion. However, the KONID Survey shows that the social identity 'religion' is by no means the most important reason for discrimination. On the contrary, religion is relatively rarely the reason for experiences of discrimination. Discrimination based on gender, political orientation, and nationality are reported much more frequently (Figs. 5.1 and 5.2).

By far the most common reason for discrimination is gender. In Switzerland in particular, women report experiences of discrimination more frequently than men: $54 \%$ of women report discrimination, with $16 \%$ experiencing it "often" or "very often" (men 31\%, respectively 6\%). In Germany, 33\% of women report discrimination, $10 \%$ experiencing it "often" or more frequently (men $34 \%$, respectively 10\%). According to the KONID Survey 2019, the experience of discrimination based on gender is particularly pronounced among women in Switzerland. ${ }^{26}$

In sum, we should note as an interim conclusion that discrimination with regard to religious identities is not uncommon in Germany and Switzerland, with discrimination occurring to approximately the same extent in both countries. About one in five respondents report discrimination based on the social identity 'religion'. Muslims are particularly affected; also affected in Switzerland are members of free churches, and in Germany, Orthodox Christians. ${ }^{27}$ However, discrimination on the basis of religious identity is by no means the most frequent reference for discrimination. Discrimination based on gender, political orientation, or nationality is more common. In addition, the stronger experiences of discrimination in the numerically smaller groups should not be underestimated in its social importance.

So far, the focus has been on experienced or perceived discrimination. In the following, the perspective is reversed. The questions now are: How strong are the mechanisms of demarcation and exclusion that emanate from religious identities? How strongly do members of certain religious communities tend to categorise others on the basis of religion? Where are the limits of tolerance regarding religious otherness, including having no religious belonging? The KONID Survey, like other surveys before, uses the "marriage question" to gain an idea of the intensity of religious boundaries and social distance. The survey question on the respondent's willingness to categorise others 
Figure 5.2: Frequency of Experiences of Discrimination in Switzerland

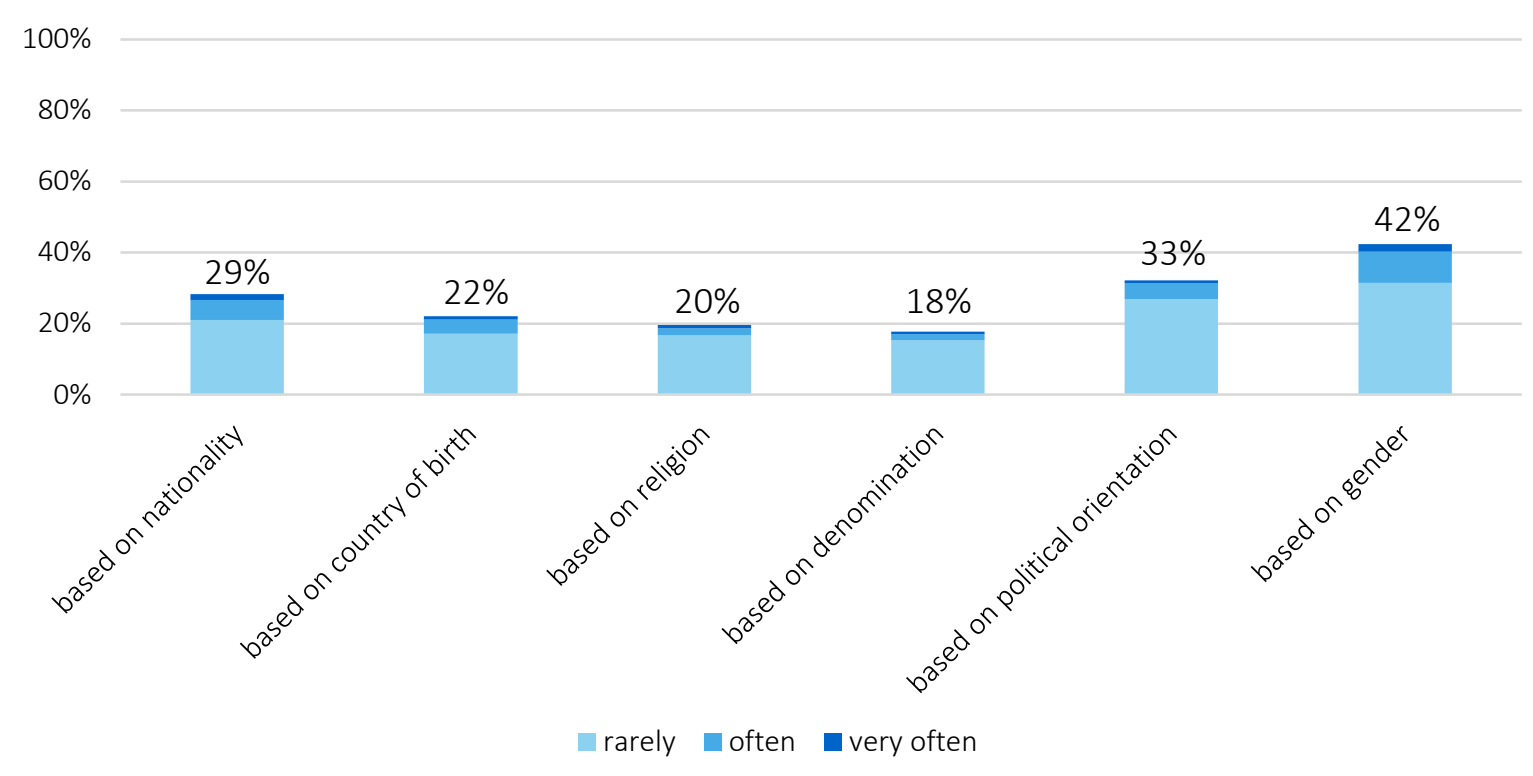

Note: The percentages are the sum of "rarely", "often" and "very often".

Source: KONID Survey CH 2019 / Figure: KONID-Team

is: "Please ignore for the moment your actual life situation and imagine you are single. Would you start a committed relationship with or marry somebody who is not ..."? - followed by the concrete naming of the respondent's social identity. The question could be answered with "no", "rather no", "rather yes", "yes" or "irrelevant". The marriage question serves to find out where the respondents draw boundaries that are extremely difficult or impossible to overcome vis-à-vis other religions and religious communities. The abstract question of marriage is therefore a proxy question to gauge a person's willingness to allow religious differences into her closest personal environment or to avoid such differences from the outset.

The exclusionary attitude is very similar in Germany and Switzerland (Tab. 5.3). 26\% of Christians in Switzerland, and 23\% of Christians in Germany, reject marriage or a committed partnership with non-Christians, while 39\% (in Switzerland) and $44 \%$ (in Germany) of Muslims reject marriage with non-Muslims. $18 \%$ of respondents without a religious affiliation in Switzerland, and $20 \%$ in Germany, would not marry someone who belongs to a religion. Members of free churches are particularly exclusionary in Switzerland, but not in Germany, with more than half of the former rejecting marriage outside their religious group. The readiness to exclude is clearly based less on the respective denomination among Christians. More decisive are the overarching global categories "Christian" and "non-Christian".

The situation differs for the groups within Islam. Among Sunnis and Shiites, the respective school is an independent and strong criterion of exclusion. This draws attention to the high religious and social significance of the differences between the inner-Islamic groups in both countries, which are presumably also linked to questions of country or regional origin.

In general, it can be concluded that exclusionary effects of the social identity 'religion' are found among all religious identities. The mutual demarcations refer above all to the broader social categories "Christian", "Muslim", and "no religious affiliation". Among members of the Catholic and Protestant (mainline) churches, the denomination has almost disappeared as a factor of exclusion with regard to the other denomination. A significant proportion of those without a religious affiliation consider their social identity of 'not belonging to religion' as a distinct boundary for a closer 
Table 5.3: Social Identities 'Religion' and 'Denomination' with regard to Social Distance Against Other Religious Belonging

\begin{tabular}{|c|c|c|c|c|c|c|}
\hline \multirow[b]{2}{*}{ Social identity } & \multicolumn{3}{|c|}{ Germany } & \multicolumn{3}{|c|}{ Switzerland } \\
\hline & $\begin{array}{c}\text { no / } \\
\text { rather no }\end{array}$ & irrelevant & $\begin{array}{c}\text { yes / } \\
\text { rather } \\
\text { yes }\end{array}$ & $\begin{array}{c}\text { no / } \\
\text { rather no }\end{array}$ & irrelevant & $\begin{array}{c}\text { yes / } \\
\text { rather } \\
\text { yes }\end{array}$ \\
\hline \multicolumn{7}{|l|}{ Christianity } \\
\hline Christian & $23 \%$ & $34 \%$ & $43 \%$ & $26 \%$ & $23 \%$ & $51 \%$ \\
\hline Catholic & $11 \%$ & $39 \%$ & $50 \%$ & $12 \%$ & $28 \%$ & $60 \%$ \\
\hline Protestant (mainline) & $11 \%$ & $36 \%$ & $54 \%$ & $7 \%$ & $26 \%$ & $67 \%$ \\
\hline Protestant free church & $15 \%$ & $33 \%$ & $53 \%$ & $53 \%$ & $8 \%$ & $39 \%$ \\
\hline Orthodox & $12 \%$ & $40 \%$ & $48 \%$ & $13 \%$ & $28 \%$ & $59 \%$ \\
\hline \multicolumn{7}{|l|}{ Islam } \\
\hline Muslim & $44 \%$ & $24 \%$ & $32 \%$ & $39 \%$ & $17 \%$ & $43 \%$ \\
\hline Sunni & $30 \%$ & $28 \%$ & $42 \%$ & $38 \%$ & $19 \%$ & $43 \%$ \\
\hline Shiite & $41 \%$ & $26 \%$ & $33 \%$ & $32 \%$ & $9 \%$ & $59 \%$ \\
\hline Alevi & $20 \%$ & $40 \%$ & $40 \%$ & $0 \%$ & $8 \%$ & $92 \%$ \\
\hline No religious affiliation & & & & & & \\
\hline a religion & $20 \%$ & $31 \%$ & $49 \%$ & $18 \%$ & $26 \%$ & $56 \%$ \\
\hline
\end{tabular}

Note: The respondents were each asked whether they would start a committed relationship with or marry somebody who is not a Christian/Muslim, etc. The responses are to be interpreted accordingly.

Source: KONID Survey DE and CH 2019 / Table: KONID-Team

relationship. Above all, however, it can be concluded that an important demarcation line in both countries actually runs between the majority population and Muslims. 22\% of Christians in Germany do not want to marry a non-Christian, i.e., also not Muslims. In Switzerland, the same goes for $26 \% .{ }^{28}$ In Germany, $44 \%$ of Muslims insist on having a Muslim partner; in Switzerland, $39 \%$. Conversely, these figures also mean that 56 and $61 \%$ of Muslims are open to relationships beyond their own faith. This should also be interpreted against the background that the reported willingness is formulated in a larger social environment, which Muslims experience as discriminatory in religious terms (see Tab. 5.2 above). Harsh social boundaries may contribute to societal polarisation. They are certainly not ideal for a free and open society. Yet, at the same time, it does not mean that all social boundaries automatically jeopardise social peace and social cohesion. In the second half of the 20th century, some countries proved that it is also possible to achieve at least peaceful coexistence and to allow for social development in polarised societies. These examples are the (at that time) pillarised society of the Netherlands, the society of Switzerland, which was organised according to denominational milieus, and the society of the early Federal Republic of Germany, which was structured according to religious camps and Weltanschauungen. Moreover, the associated conflicts are not a source of danger per se. After all, a certain amount of conflict is the norm for democratic collectives, and are not disruptive. The direction of the community is decided in the process of negotiating between differing interests.

Therefore, it is not trivial to determine which attitudes and beliefs are to be regarded as so divisive that they represent a potential threat to liberal democracies. Democracies based on the rule of law thrive on guaranteed human rights as well as on parliaments and governments that are legitimised by elections and oriented towards the will of the majority. This includes freedom of religion. But it also means that the political system, in the interest of freedom for all, establishes the framework 
for religious practice and the political role of religions. Religions may defend and advocate their own understanding of truth. However, the respective understanding of truth must not become the practical ideal for political rule and state coercion. ${ }^{29}$ This would mean abandoning the foundations of a democracy with an open society, and crossing the border to anti-democratic extremism - at least in thought.

There are three items in the KONID Survey that focus on such a border crossing and its possible repercussions. The questions or rather statements are: "In a case of conflict, the rules and values of my religion are more important than the constitution of Germany/ Switzerland"; "Religion should be the only and ultimate political authority"; "I would be prepared to act to ensure my religious convictions prevail, using violence if necessary". Each question could be answered with "strongly disagree", "somewhat disagree", "somewhat agree", or "strongly agree".

The frequency with which people agree with these statements (which become increasingly indicative of extremism) give cause for concern (Fig. 5.3).

Figure 5.3: Anti-Democratic Religious-Political Attitudes

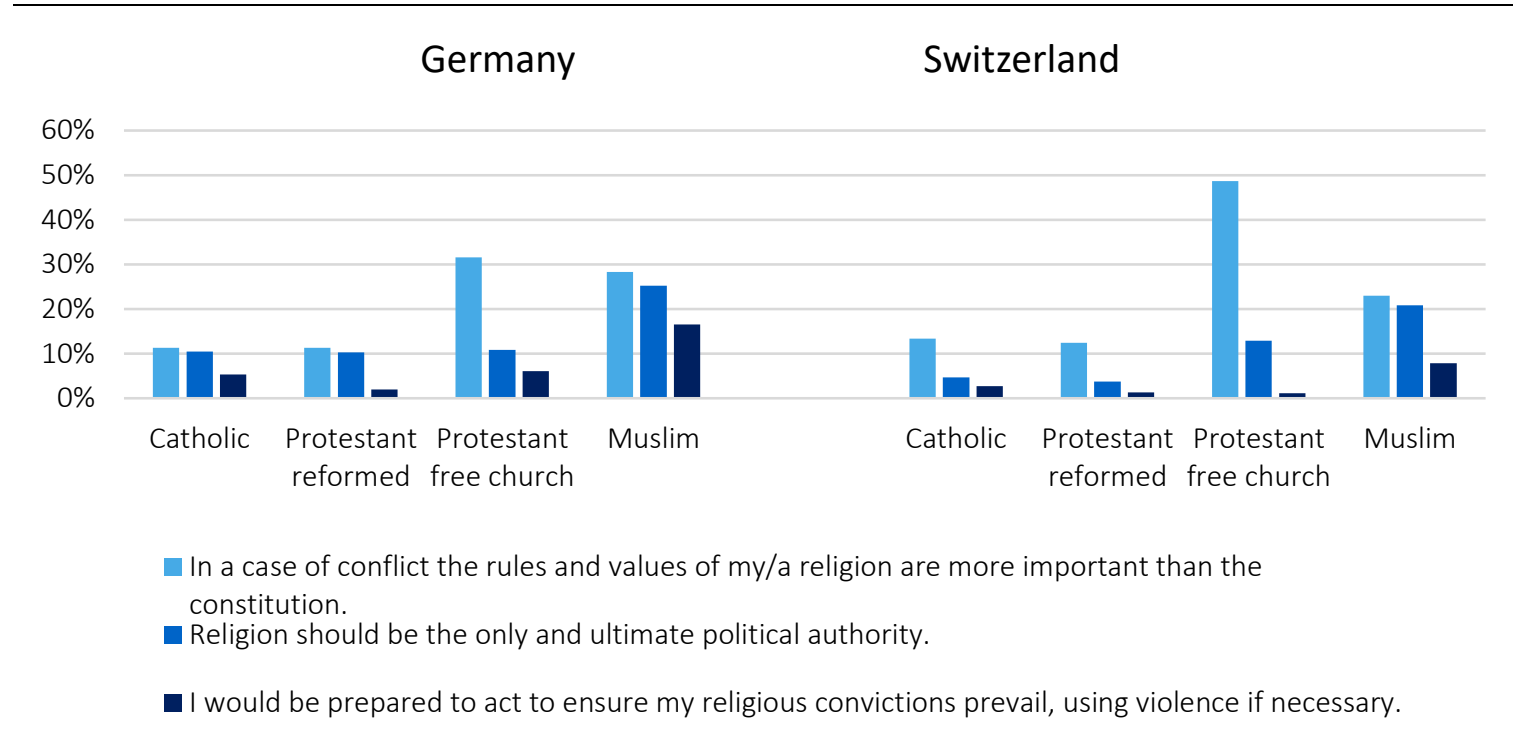

Note: Percentage of agreement, calculated by combining "strongly agree" and "somewhat agree". For ease of visibility of relations to total population, the scale runs from 0 to $60 \%$.

Source: KONID Survey DE and CH 2019 / Figure: KONID-Team

In the order of the three questions, in Germany, 11, 11 and 5\% of Catholics agreed; in Switzerland, 13,5 and $3 \%$ (sum of "somewhat agree" and "strongly agree" for each percentage). Among the Protestant reformed in Germany, 11, 10 and 2\% agree; in Switzerland, 12, 4 and 1\%. As for members of free churches in Germany, 32, 11 and 6\% agree; in Switzerland, 49, 13 and 1\%. Among Muslims in Germany, the figures are 28, 25 and 17\%; in Switzerland, 23, 21 and 8\%.

There is therefore a certain potential for people among all religious traditions to absolutise their own religious views and convictions with regard to democracy and the state, with agreement being particularly high among members of free churches and Muslim communities. Of course, only a minority within these groups hold consistent positions that can be summarised as dogmatic or fundamentalist. The real size of these minorities hardly coincides with the generalised threat scenarios that prevail in the media and public debates on "Islam" in both countries. In particular, Muslim respondents do show a higher readiness to enforce religious convictions with violence. Judged normatively, these figures are quite disturbing. However, overall the main point is that this phenomenon occurs across all religions. Therefore, the politically relevant problem is, first of all, to obtain a 
general view of dogmatic extremist positions. Secondly, these positions need to be addressed with the religious communities themselves in order to take preventive action. This seems promising, since in all religious groups about four-fifths of these (potentially) extremist people are actively tied to their religious community. The fact that these attitudes are more frequent among Muslim respondents is likely to have many different causes and requires further research. ${ }^{30}$ Initial multivariate investigations across all the groups mentioned indicate that this is primarily a cumulative effect of the level of education, political orientation on the left-right scale, and personal religiosity. Particularly among Muslims, the lack of contact with people without a religious affiliation, the importance of the social identity 'religion', experiences of discrimination on the basis of political orientation and religion, as well as the experience of migration and inequality, also have an effect. The stronger these factors are, the higher the rates of agreement on the statements reported. 


\section{Religious identity and social cohesion}

Already in the 1950s, the first generation of researchers on prejudice knew that religions are ambivalent when it comes to investigating what separates and unites society. ${ }^{31}$ This is still the case today. Pro-social impulses also emanate from religion - even in more secularised societies such as Germany and Switzerland. ${ }^{32}$ This becomes visible if we look at the links between religion and civil society. A vibrant civil society is generally regarded as essential for the functioning and continued existence of democracy and its liberal social order. ${ }^{33}$

Civil society is defined here as the intermediary, public sphere of social self-organisation between the state, the economy, culture/religion, and the private sphere. ${ }^{34}$ At the heart of civil society is the civic engagement of citizens. The KONID Survey uses the established survey instrument of a German standard survey called Freiwilligensurvey to measure people's involvement in civic engagement. ${ }^{35}$ The first step is to clarify the level and forms of the involvement. The opening question asks for taking part in activities of various sectors of civil society, including activities like "sport, exercise and fitness", "leisure and socialising", "politics and political representation", and "activities in the religious area". The latter explicitly refers to activities that do not belong in the narrower sense to religious practices such as attending church services. In the second step, those who indicate that they are active in at least one area are asked a follow-up question about voluntary work: "Now we would like to know whether any of these activities in the different areas are performed voluntarily or in an honorary capacity. This means that you are not paid to do these tasks or activities (or you only receive a very small allowance). ... You said that you are active in the area of religion. Have you currently taken on any tasks or work in this area which you perform voluntarily or in an honorary capacity?" This question was asked for each of the areas of activity mentioned.

\section{Table 6.1: Civic Engagement in Germany and Switzerland}

\begin{tabular}{lcc}
\hline & Germany & Switzerland \\
\cline { 2 - 3 } Rate of civic engagement (formal and informal volunteering) & $54 \%$ & $48 \%$ \\
\hline Area of sport, exercise and fitness & $20 \%$ & $18 \%$ \\
Area of leisure and socialising & $17 \%$ & $10 \%$ \\
Social area & $19 \%$ & $5 \%$ \\
Area of culture and music & $13 \%$ & $10 \%$ \\
Religious area & $11 \%$ & $8 \%$ \\
Area of school, nursery or kindergarten & $14 \%$ & $5 \%$ \\
Area of environment, nature conservation or animal welfare & $13 \%$ & $5 \%$ \\
Area of extra-curricular children's and youth groups & $10 \%$ & $7 \%$ \\
Area of politics and political representation & $7 \%$ & $4 \%$ \\
Other area & $6 \%$ & $4 \%$ \\
\hline
\end{tabular}

Note: The KONID Survey recorded civic engagement with the survey instrument of the Freiwilligensurvey, which records formal and informal voluntary work together, with multiple answers being possible.

Source: KONID Survey DE and CH 2019 / Table: KONID-Team

In both countries, the religious area is in the upper middle range when it comes to civic engagement (Tab. 6.1). In 2019, around $11 \%$ of the population volunteered in the religious area in Germany, and around $8 \%$ in Switzerland. For comparison, the top position in both countries is occupied by sports, with 20 and $18 \%$ respectively. 
Figure 6.1: Religiosity and Civic Engagement

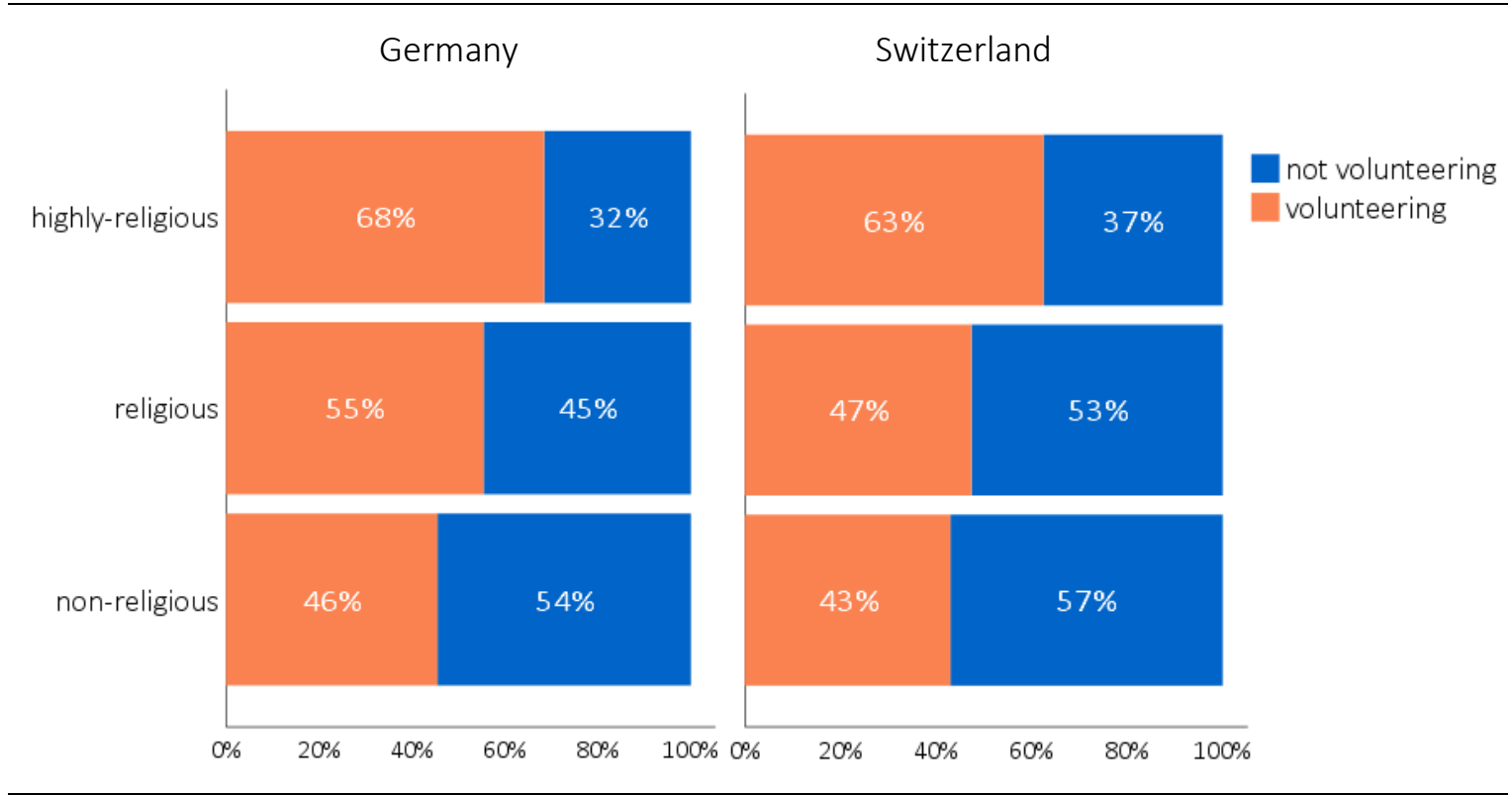

Source: KONID Survey DE and CH 2019 / Figure: KONID-Team

The frequency of civic engagement in the area of politics is only 7 and $4 \%$ respectively. By comparison, this means that a significant proportion of civic engagement in both countries comes from the religious realm. Moreover, in the case of voluntary work, the connections between the religious domain and civil society are more pronounced than one would expect in view of the decline of church attendance, baptisms and marriage ceremonies. ${ }^{36}$

If we switch from the previously considered meso level of organised civil society to the individual level of the volunteers themselves, the KONID data show the continuing importance of the social identity 'religion' as well as a person's religiosity for the preponderance of voluntary work (Fig. 6.1).

In Germany, almost $70 \%$ of the highly religious volunteer; $55 \%$ of the religious; and only $46 \%$ of the non-religious. The picture is very similar for Switzerland, albeit at a slightly lower lever: $63 \%, 47 \%$, and $43 \%$ respectively. Previous studies have shown that these differences also persist when controlling for variables such as gender, age, education, and migration. Consequently, the findings suggest that the effect (also) originates from religiosity itself. ${ }^{37}$ Furthermore, the KONID data show that the self-classification of the respondents as religiously conservative or religiously liberal does not affect the level of volunteering (Tab. 6.2). ${ }^{38}$

Table 6.2: Civic Engagement According to Self-Classification as Religiously Conservative or Liberal

\begin{tabular}{lcccc}
\hline & \multicolumn{2}{c}{ Germany } & \multicolumn{2}{c}{ Switzerland } \\
\cline { 2 - 5 } Self-classification & volunteering & not volunteering & volunteering & not volunteering \\
\hline religiously conservative & $55 \%$ & $45 \%$ & $53 \%$ & $47 \%$ \\
religiously liberal & $58 \%$ & $42 \%$ & $50 \%$ & $50 \%$ \\
\hline
\end{tabular}

Source: KONID Survey DE and CH 2019 / Table: KONID-Team

Thus, civic engagement is a matter not of the content of faith, but of religious motivation as such. ${ }^{39}$ At the same time, this also means that in respective communities and associations those who are active and engaged come from different strands of understanding their respective religious tradition. 
Figure 6.2: Civic Engagement According to Importance of Social Identity 'Religion'

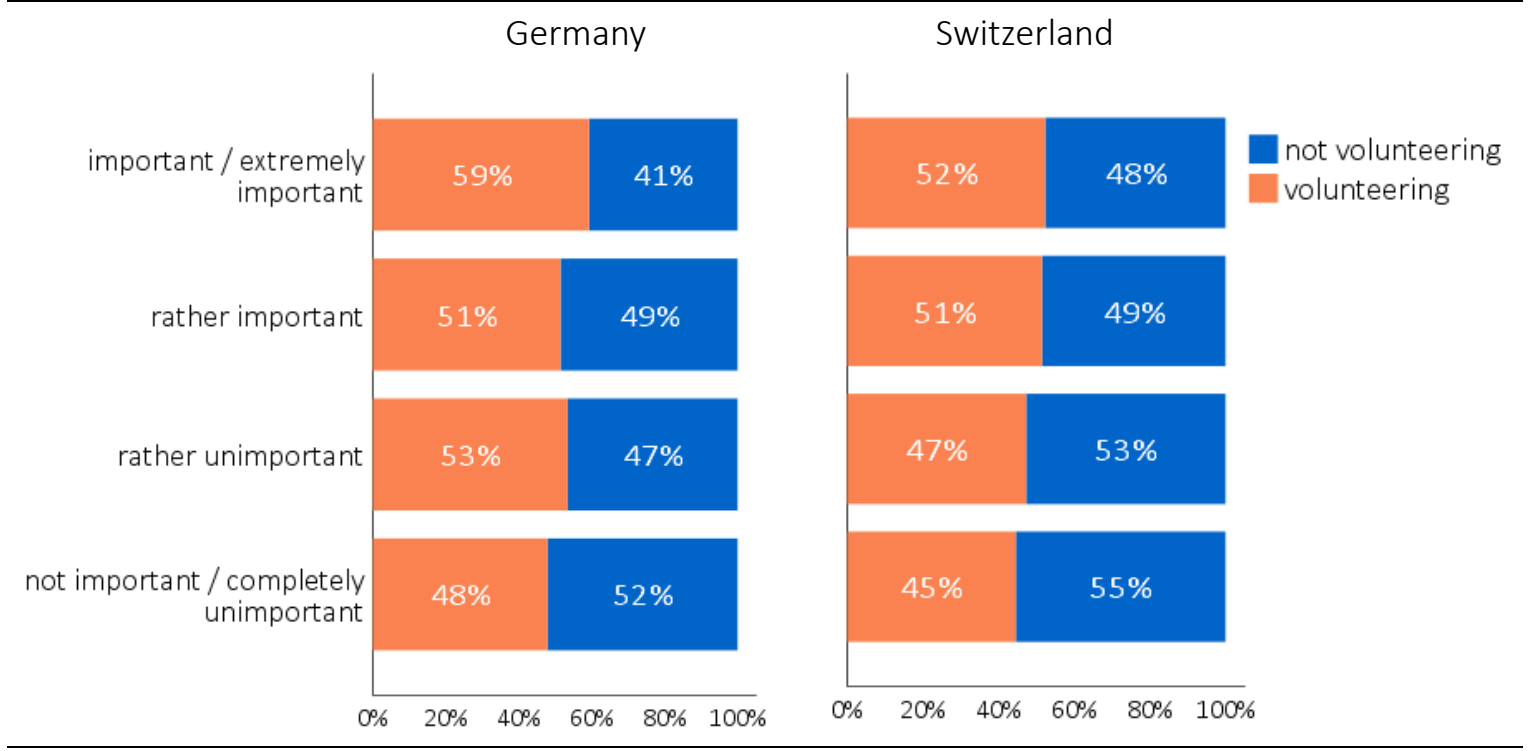

Source: KONID Survey DE and CH 2019 / Figure: KONID-Team

According to the previous elaborations on the relationship between religious identity and religiosity (see chapter 3 above), it could be expected that the social identity 'religion' influences the commitment to civic engagement as well. The data show that the more important the social identity 'religion' is to the respondents, the more often they are also involved in civil society (Fig. 6.2). In Germany, those who regard their religious identity as extremely important volunteer more often (59\%) than those to whom the social identity 'religion' is completely unimportant (48\%). The same pattern is evident in Switzerland, where the difference is not quite as large but nevertheless visible (52 to $45 \%)$. However, these differences do not result in a statistically robust correlation. ${ }^{40}$ More important in this respect is integration in a religious group. The very fact that a person belongs to a religious community positively affects whether she or he is involved in civic engagement (Tab. $6.3)^{41}$

Table 6.3: Civic Engagement and Religious Affiliation

\begin{tabular}{|c|c|c|c|c|}
\hline \multirow[b]{2}{*}{ Religious affiliation } & \multicolumn{2}{|c|}{ Germany } & \multicolumn{2}{|c|}{ Switzerland } \\
\hline & volunteering & $\begin{array}{c}\text { not } \\
\text { volunteering }\end{array}$ & volunteering & $\begin{array}{c}\text { not } \\
\text { volunteering }\end{array}$ \\
\hline Catholic & $58 \%$ & $42 \%$ & $48 \%$ & $52 \%$ \\
\hline Protestant (mainline) & $54 \%$ & $46 \%$ & $57 \%$ & $43 \%$ \\
\hline Protestant free church & $55 \%$ & $45 \%$ & $75 \%$ & $25 \%$ \\
\hline Christian Orthodox & $69 \%$ & $31 \%$ & $39 \%$ & $61 \%$ \\
\hline Muslim & $36 \%$ & $64 \%$ & $31 \%$ & $69 \%$ \\
\hline no religious affiliation & $49 \%$ & $51 \%$ & $42 \%$ & $58 \%$ \\
\hline
\end{tabular}

Source: KONID Survey DE and CH 2019 / Figure: KONID-Team

These interrelationships require more detailed analyses in the further course of the KONID project. Above all, multivariate analyses are needed to gain more precise insights into cause-and-effect mechanisms. The initial findings presented here already show that the variables of religiosity, religious affiliation, and social identity 'religion' always have a positive effect on volunteering. To be more precise: involvement in religion and individual religiosity have above all a beneficial effect on civic engagement and, thus, on the vibrancy of civil society. 
Further differences regarding the rate of volunteering become apparent when we differentiate according to formal religious affiliation. These differences exist both between the religious communities and between the two countries (Tab. 6.3). In Germany, the differences are not strong between Catholics, members of Protestant mainline churches, and members of Protestant free churches. In Switzerland, by contrast, members of free churches are strongly involved in volunteering (75\%). Also, members of Protestant reformed churches rank above the average (57\%), while members of the Catholic Church fall into the average range (48\%). In both countries, members of Muslim communities are strongly under-represented when it comes to civic engagement. In Germany, $36 \%$ of the Muslim population volunteer; in Switzerland, 31\%. When assessing this low rate, we should bear in mind that voluntary work usually means taking on smaller or larger leadership tasks, which requires cultural familiarity, a particular language competence, and often a higher level of education. Therefore, it is no coincidence that, according to the findings of research on civil society, those who are overrepresented in terms of engagement in civil society are middle-aged people who are successful in their careers. ${ }^{42}$ Many of the Muslim respondents have an initial disadvantage here, often also due to their immigrant background. As with other issues of social inclusion, the difference will probably diminish with each successive generation.

An important question regarding the quality of volunteering in civil society is whether the newly established social relationships only reinforce existing contacts and possibly even promote demarcations ("bonding social capital"), or whether the contacts lead to new networks and thus to better social cohesion ("bridging social capital"). The data of the KONID Survey 2019 make it possible to investigate these relationships. One of the key questions for this purpose is: "During these voluntary activities, what type of people do you come into contact with? Would you say that you are brought together with people whom you would not otherwise meet in your everyday life?" The vast majority of those involved in civic engagement (across all areas) answer the latter question in the affirmative (Tab. 6.4).

Table 6.4: Bridging Social Capital by Area of Civic Engagement

\begin{tabular}{lllr}
\hline \multicolumn{1}{c}{ Germany } & \multicolumn{2}{l}{ Switzerland } \\
\hline Area & Share & Area & Share \\
\hline Politics and political representation & $74.1 \%$ & Crisis assistance, first aid or civil prot. & $82.2 \%$ \\
Sport, exercise and fitness & $71.6 \%$ & School, nursery or kindergarten & $68.8 \%$ \\
Religious area & $71.1 \%$ & Culture and music & $67.8 \%$ \\
Crisis assistance, first aid or civil prot. & $70.7 \%$ & Politics and political representation & $67.5 \%$ \\
School, nursery or kindergarten & $70.1 \%$ & Religious area & $63.4 \%$ \\
Social area & $69.9 \%$ & Extra-curr. children's and youth groups & $63.2 \%$ \\
Environment, nature conservation, etc. & $68.3 \%$ & Sport, exercise and fitness & $62.4 \%$ \\
Leisure and socialising & $68.2 \%$ & Social area & $61.9 \%$ \\
Extra-curr. children's and youth groups & $67.7 \%$ & Environment, nature conservation, etc. $60.6 \%$ \\
Culture and music & $66.5 \%$ & Leisure and socialising & $59.7 \%$ \\
\hline
\end{tabular}

Note: The proportion refers to those people per area who state that, through their voluntary commitment, they come into contact with people whom they would otherwise not meet in everyday life.

Source: KONID Survey DE and CH 2019 / Table: KONID-Team

In Germany, $71 \%$ of those active in the context of religion state that through their involvement they come into contact with people whom they would otherwise not meet; in Switzerland, the figure is $63 \%$. Considering that the proportion of "yes" answers is slightly higher overall, the rate of agreement among those involved in the religious area is in the middle range, and in Germany in the upper middle range. Thus, the religious sector, like the other areas, helps to create bridging social capital 
in society. That civic engagement is also a source of personal enrichment and fulfilment can be seen from the fact that those involved consider their involvement to be important for their social identity (see chapter 4 above).

A key assumption of Social Capital Theory is that contact or civic engagement significantly increases the available social capital of a society at the macro level, too. ${ }^{43}$ This pro-social effect of civic engagement and social contact is - according to the theory - reflected in the spread of generalised trust in society. The mechanism seems plausible: those who repeatedly experience the value and reliability of social relationships and social exchange in their everyday lives also transfer this trust to fleeting encounters and to social togetherness in a society in general. The KONID Survey also measures the strength of this general trust. Respondents were asked the following question: "Generally speaking, would you say that most people can be trusted or that you need to be very careful in dealing with people?" For an answer, they could choose one of the two views that suited them best. The findings are mixed when we consider the variables used so far in this chapter: namely, social identity 'religion', religiosity, self-classification as religiously conservative or liberal, and formal religious affiliation (Tab. 6.5).

Table 6.5: Religion and Generalised Trust in Germany and Switzerland

\begin{tabular}{|c|c|c|}
\hline & Germany & Switzerland \\
\hline & \multicolumn{2}{|c|}{ Generalised trust } \\
\hline \multicolumn{3}{|l|}{ Importance of social identity 'religion' } \\
\hline important/ extremely important & $52 \%$ & $63 \%$ \\
\hline rather important & $51 \%$ & $72 \%$ \\
\hline rather unimportant & $59 \%$ & $72 \%$ \\
\hline $\begin{array}{l}\text { not important/ completely } \\
\text { unimportant }\end{array}$ & $61 \%$ & $71 \%$ \\
\hline \multicolumn{3}{|l|}{ Religiosity (CRS-scale) } \\
\hline highly religious & $52 \%$ & $73 \%$ \\
\hline religious & $56 \%$ & $70 \%$ \\
\hline not religious & $54 \%$ & $62 \%$ \\
\hline \multicolumn{3}{|l|}{ Self-classification } \\
\hline religiously conservative & $41 \%$ & $58 \%$ \\
\hline religiously liberal & $63 \%$ & $74 \%$ \\
\hline \multicolumn{3}{|l|}{ Religious affiliation } \\
\hline Catholic & $58 \%$ & $68 \%$ \\
\hline Protestant (mainline) & $52 \%$ & $77 \%$ \\
\hline Protestant free church & $45 \%$ & $83 \%$ \\
\hline Christian Orthodox & $27 \%$ & $53 \%$ \\
\hline Muslim & $37 \%$ & $38 \%$ \\
\hline No religious affiliation & $58 \%$ & $67 \%$ \\
\hline
\end{tabular}

Source: KONID Survey DE and CH 2019 / Figure: KONID-Team

What stands out first is the overall difference in level between Germany and Switzerland. Although general trust is at a high level in both countries, it is even higher in Switzerland than in Germany. With regard to the religion-related variables, generalised social trust in Germany increases with the decreasing importance of the social identity 'religion'. In Switzerland, only those for whom religion is important as a social identity fall short of the other categories of the social identity 'religion' variable, i.e. "rather important", "rather unimportant" and "not important/ completely 
unimportant". Moreover, personal religiosity does not have a strong influence in Germany. In Switzerland, by contrast, general trust increases with higher religiosity - of the very religious, $73 \%$ claim general confidence; of the non-religious, $63 \%$. Furthermore, self-classification as religiously conservative or liberal has a surprisingly strong influence. In both countries, respondents with a liberal religious attitude show a much higher general level of trust than those with conservative views. Finally, when differentiated according to formal religious affiliation, the level of trust among religious minorities in Germany is lower than among the majorities with and without a religious affiliation. In Switzerland, it is precisely members of free churches who trust in people the most (83\%). Reformed respondents trust others slightly more often than Catholic respondents and those with no religious affiliation. In both countries, fewer than $40 \%$ of Muslims generally trust most other people, which is well below average.

It is not easy to identify a common denominator here. Only concerning the respective self-classification as religiously liberal or conservative does there seem to be a general effect. For the other variables, this is not the case at all, or it is only to a very limited extent. The much lower level of trust among Muslim respondents still needs explaining. Certainly, immigration and in particular the experiences gathered from the countries of origin have some influence here. In countries with a young or no democracy, general trust is usually very low. Against this background, a cautious conclusion could be that religion in its different variants has a share in a socially beneficial spread of generalised trust. However, in contrast to our findings on civic engagement, religion does not have an effect of its own that goes beyond the average level of general trust. If respondents consider religion as a social identity to be important, then the level of trust even decreases somewhat. But, if religion is coupled with a religiously liberal attitude, trust in other people increases significantly. Apparently, a more in-depth analysis is required here.

Finally, this chapter takes a closer look at how the diversity of religious identities is dealt with in the public domain. For this purpose, we highlight two central aspects: on the one hand, the readiness for dialogue between the religions and across religious boundaries; on the other, the socio-political handling of diversity of religions and related matters (Weltanschauungen). The core of a liberal society is the fundamental right to religious freedom. It encompasses the freedom of thought, conscience and religion for individuals as well as communities and larger institutionalised groups.

The question "How strongly do you agree or disagree with each of the following statements? ... In my personal view, interreligious dialogue is important" was answered on a four-point scale ranging from "strongly agree" and "somewhat agree" to "somewhat disagree" and "strongly disagree". 52\% of respondents in Germany ${ }^{44}$ and $48 \%$ in Switzerland opted for either "strongly agree" or "somewhat agree". Focusing on the social identity 'religion', a clear correlation exists for both countries (Tab. 6.6): those who care about their social identity 'religion' are more strongly in favour of interreligious dialogue (66\% in Germany, and 60\% in Switzerland), and those who do not attach any importance to their social identity 'religion' the proportion falls to 38 and $34 \%$ respectively.

This effect is even stronger with regard to religiosity. One might expect that especially the very religious would want to avoid such dialogue. However, this is not the case. In Germany, dialogue is important for $85 \%$ of them; in Switzerland, for $71 \%$. For the non-religious, the rate of agreement drops dramatically to 25 and $31 \%$ respectively. It is noteworthy that on this issue there is no difference between those who are religiously liberal and those who are religiously conservative. 
Table 6.6: Importance of Social Identity 'Religion' and Political Attitudes Towards Religion and State

\begin{tabular}{lcccccc}
\hline & $\begin{array}{c}\text { In my personal } \\
\text { view, interreligious } \\
\text { dialogue is } \\
\text { important }\end{array}$ & $\begin{array}{c}\text { Freedom of } \\
\text { religion is a } \\
\text { good thing }\end{array}$ & $\begin{array}{c}\text { Democracy } \\
\text { is the best } \\
\text { form of } \\
\text { government }\end{array}$ \\
\cline { 2 - 9 } & & \multicolumn{7}{c}{ Agreement } \\
Importance of Soc. Id. Religion & $\mathrm{DE}$ & $\mathrm{CH}$ & $\mathrm{DE}$ & $\mathrm{CH}$ & $\mathrm{DE}$ & $\mathrm{CH}$ \\
\hline $\begin{array}{l}\text { important/ extremely important } \\
\text { rather important }\end{array}$ & $66 \%$ & $60 \%$ & $93 \%$ & $95 \%$ & $89 \%$ & $95 \%$ \\
rather unimportant & $47 \%$ & $53 \%$ & $91 \%$ & $96 \%$ & $91 \%$ & $94 \%$ \\
not important/ completely & $40 \%$ & $44 \%$ & $92 \%$ & $97 \%$ & $91 \%$ & $98 \%$ \\
unimportant & $38 \%$ & $34 \%$ & $90 \%$ & $97 \%$ & $87 \%$ & $96 \%$ \\
\hline
\end{tabular}

Note: Agreement is measured as the combination of "somewhat agree" and "strongly agree". Source: KONID Survey DE and CH 2019 / Table: KONID-Team

With regard to religious affiliation, the highest agreement is found among members of free churches and among Muslims. In Germany, $78 \%$ of people who belong to a free church and $87 \%$ of Muslims consider interreligious dialogue to be important. In Switzerland, the same applies to 61\% of members of free churches and to $63 \%$ of Muslims. The differences between the two countries concerning the level of agreement cannot be explained by the data, but could relate to the prevalence of, or need for, such platforms for dialogue in society. Effects of social desirability could also come into play. Overall, the two countries are similar on this question. The vast majority of those who are more closely associated with religion - be it because of the importance of their religious identity or the intensity of religiosity - regard interreligious dialogue as an important matter. Again, to formulate this in a deliberately normative and evaluative way, we can see that support for interreligious dialogue is fortunately strongest among religious minorities and especially Muslim respondents. Here, the great potential for social dialogue becomes apparent. The majority groups are called upon to take this potential seriously. It should be taken up as part of the task of achieving integration in a diverse society. ${ }^{45}$

Finally, there is broad consensus in favour of freedom of religion. The question asked was: "How much do you agree with the following statement? ... Freedom of religion is a good thing". Regardless of whether a person has or has no religious affiliation, the rate of agreement, i.e. the sum of "somewhat agree" and "strongly agree", in both countries is over $90 \%$, and is particularly high among religious minorities. In Germany, 94\% of members of free churches and 92\% of Muslims support this fundamental right. In Switzerland, the rate even climbs to 98 and $96 \%$ respectively. In both countries, this indicates that minorities are aware of the protective function of the fundamental right to religious freedom. It is not different with regard to the social identity 'religion' and individual religiosity: the basic consensus is that religious differences should be mutually recognised on the basis of freedom of religion for all, and that people should be free to practise their religion. The fundamental and human right to freedom of religion is a common foundation accepted by all, and nearly everyone stands up for its binding character. This is true at least on the theoretical level, but probably also for most everyday practices. In this way, too, religious diversity can unite society and promote a sense of social cohesion. 


\section{How religious identity structures society: five configurations of so- cial identities in Germany and Switzerland}

The KONID Survey focuses on religion as a social identity. We have discussed in detail its importance for the individual and the importance of religion in the context of other social identities. So far, all statements have referred to characteristics of individual respondents or of groups such as religious communities. At the level of the respondents, a survey instrument with 21 variables and six possible answer options each results in an unmanageably large number of possible combinations. In mathematical terms, excluding refusals to reply, there are $6^{21}$ or $21,936,950,640,377,856$ possible combinations of answers regarding the importance of social identities. For everyday life, this means that the actual combinations of social identities can be manifold, and that social life can always hold surprises in store. Social identities tend to be subject to little standardisation in liberal societies, and a certain "colourfulness" of identities can be expected under such circumstances. ${ }^{46}$ But are these conditions also completely confusing? Or are there nevertheless recognisable patterns or configurations of social identities in both societies?

According to the results of the KONID project, the answer to these questions is clear. If one switches the level of analysis from the individual and groups to the macro level of society, regularities can be seen in the individual diversity of social identities for Germany and Switzerland. These regularities are even very similar for the countries in question.

A cluster analysis makes such patterns apparent and verifiable at the macro level. The cluster analysis uses an algorithm to investigate whether patterns or configurations exist in the population. In addition, it evaluates how many and which configurations divide and thus represent the population best. For Germany and Switzerland, a solution with five clusters has proven to be the best for determining configurations along the 21 social identities. ${ }^{47}$ It is part of the cluster analysis that every respondent is assigned to one of the five configurations. However, the naming of the clusters is up to the researchers and therefore an interpretative exercise based on the parameters of the analysis. The boundaries between the five configurations are somewhat fuzzy, which is due to the diversity of the output data already mentioned. Consequently, we speak only of a shared "orientation" for each configuration.

The five configurations of social identities identified for Germany and Switzerland are roughly the same. However, they differ in specific sub-aspects. The visual representation of the configurations is therefore country-specific (Figs. 7.1 and 7.2). In relation to the population, the "belonging-oriented" form the largest configuration, with $27 \%$ in Germany, and $24 \%$ in Switzerland. The next configurations are the "surroundings-oriented", with 22 and $21 \%$ respectively, followed by the "religion-oriented", with 21 and 19\%. The fourth configuration are the "family-oriented", with 17 and 19\% respectively; the fifth, the "self-oriented", with 13\% in Germany, and 17\% in Switzerland.

What characteristics do these labels and the people assembled in the respective configuration have? The belonging-oriented generally attach great importance to all their social identities, including religion. In addition to family and religion, friends, neighbours, and the regional surroundings are important in Germany; in Switzerland, it is above all gender that is important to members of the belonging-oriented configuration. Also, the nation and other regional belongings are held in high esteem. In both countries, an above-average proportion of women belongs to this configuration. To sum up, the configuration gathers people to whom numerous social 


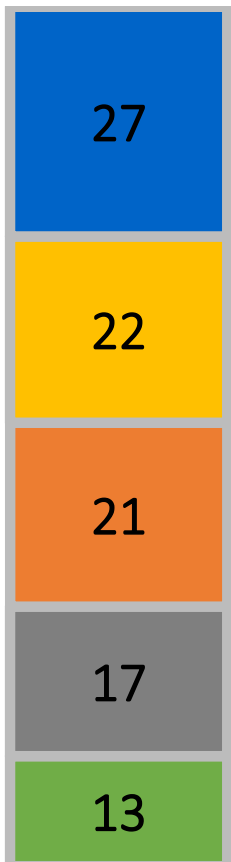

Belonging-oriented: Social identities are generally of great importance. Besides family and religion, friends and neighbours, as well as the regional belonging play an important role.

Surroundings-oriented: Social identities are of medium importance overall. Family and religion play no role. The regional belonging is of higher relevance.

Religion-oriented: Religion and family are particularly important. Other social identities are less important in comparison.

Family-oriented: Family and friends are especially important. Religion is less important, and the regional belonging is particularly unimportant.

Self-oriented: Social identities play a subordinate role. Family, friends, and sports are still of medium importance. Religion is completely unimportant.

Note: The numbers in the boxes of each configuration indicate the respective size in per cent.

Source: KONID Survey DE 2019 / Figure: KONID-Team

identities are very important. Their social identity is oriented towards and strongly determined by group affiliations of all kinds.

The surroundings-oriented also take the whole range of social identities into account. Group affiliations are certainly regarded as positive, but they are not as decisive as for the belonging-oriented. The surroundings-oriented take into account social identities and the group affiliations that might arise from them. Yet, they do so without giving these social identities strong weighting for their personal social identity. The orientation is based on the social environment, but, without that, the self-definition is strongly shaped by the respective affiliations. What is particularly striking for Switzerland is that marital status is rather unimportant in this cluster. In particular, the categories "single" and "widowed" are not considered important social identities for the respondents. Social identity is not defined by these two characteristics in Switzerland. In Germany, family generally plays a subordinate role in this configuration. The same applies to religion. More important is one's association with the residential region. Yet, in sum, for surroundings-oriented social identities are not of central importance or particularly decisive, but they are taken into account.

In both countries, the religion-oriented are those who, compared to all other social identities, give religion or the fact that they have no religion the highest priority. The dominance of the social identity 'religion' is the feature that distinguishes members of this cluster from the rest of the population. 
Figure 7.2: Configurations of Social Identities in Switzerland

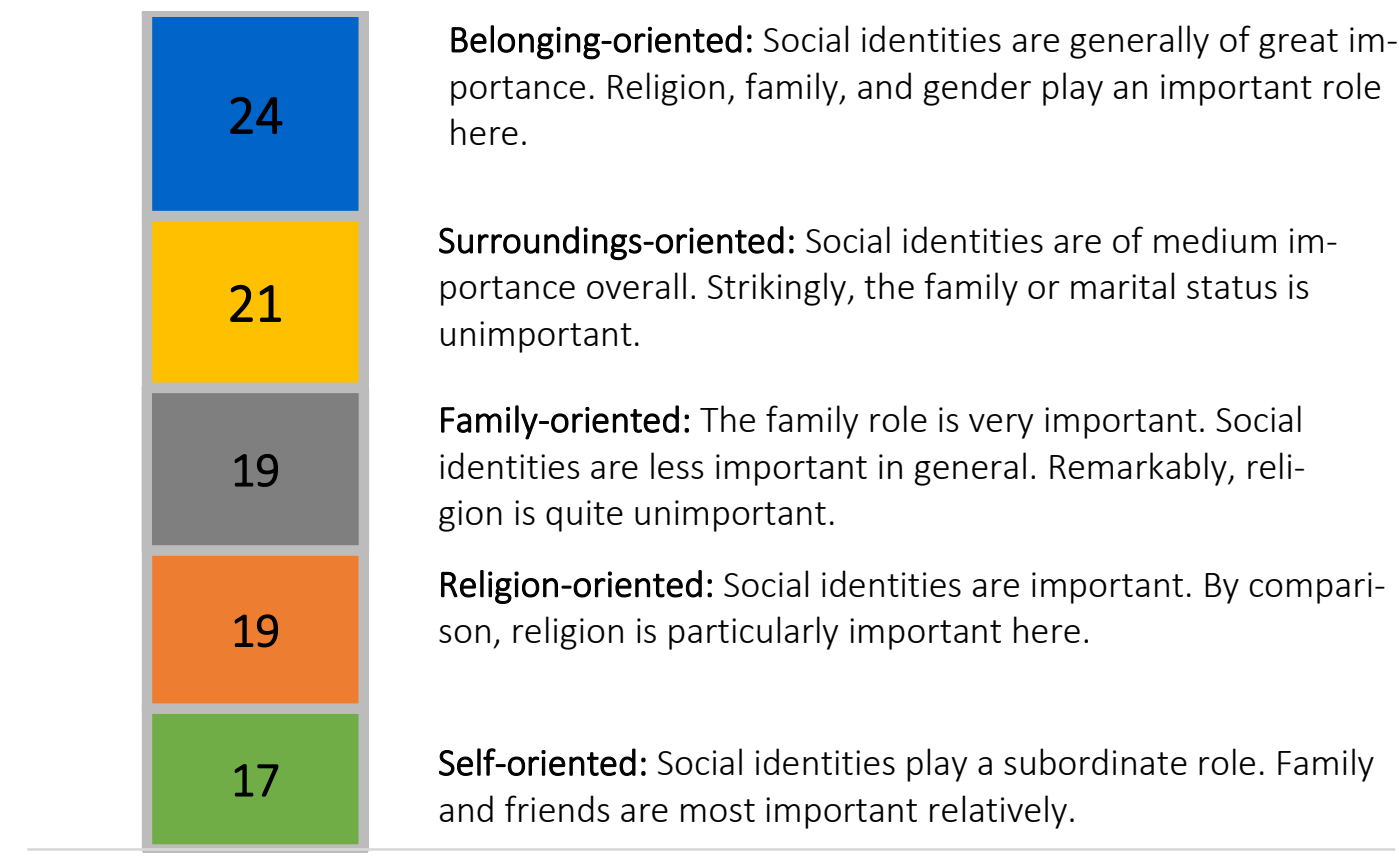

Note: The numbers in the boxes of each configuration indicate the respective size in per cent.

Source: KONID Survey CH 2019 / Figure: KONID-Team

The family-oriented in both countries unites that their roles in the family are particularly important for their social identity. In contrast, religion only plays a subordinate role in this configuration. Overall, the orientation here is more secular. Other potentially superordinate collective identities, such as nationality, the federal state, or canton, are also of secondary importance. The circle of family and friends defines social identity most strongly in this cluster.

The self-oriented generally do not attach importance to social identities. If anything, it is family and friends that carry weight. Religion is unimportant in both countries, although it is even somewhat less important in Germany than in Switzerland.

Most interesting is the distribution of religious affiliation within the five configurations of social identities (Figs. 7.3 and 7.4). Of course, people from all five configurations can be found in all major religious groups. Once again, this corresponds to the image and reality of plural societies with a high degree of freedom of individuals to assign to various social groups. However, not all religious groups are equally represented in all configurations. In Germany, most people with a religious affiliation are found among the belonging-oriented, followed by the religion-oriented. Members of free churches are very strongly represented among the religion-oriented. Muslims are particularly strongly allocated to the belonging-oriented and religion-oriented on the one hand, and to the selforiented on the other. This probably reflects differences within Islam in terms of how Muslims position themselves with regard to their own religious tradition. 
Figure 7.3: Religious Affiliation within the Five Configurations in Germany

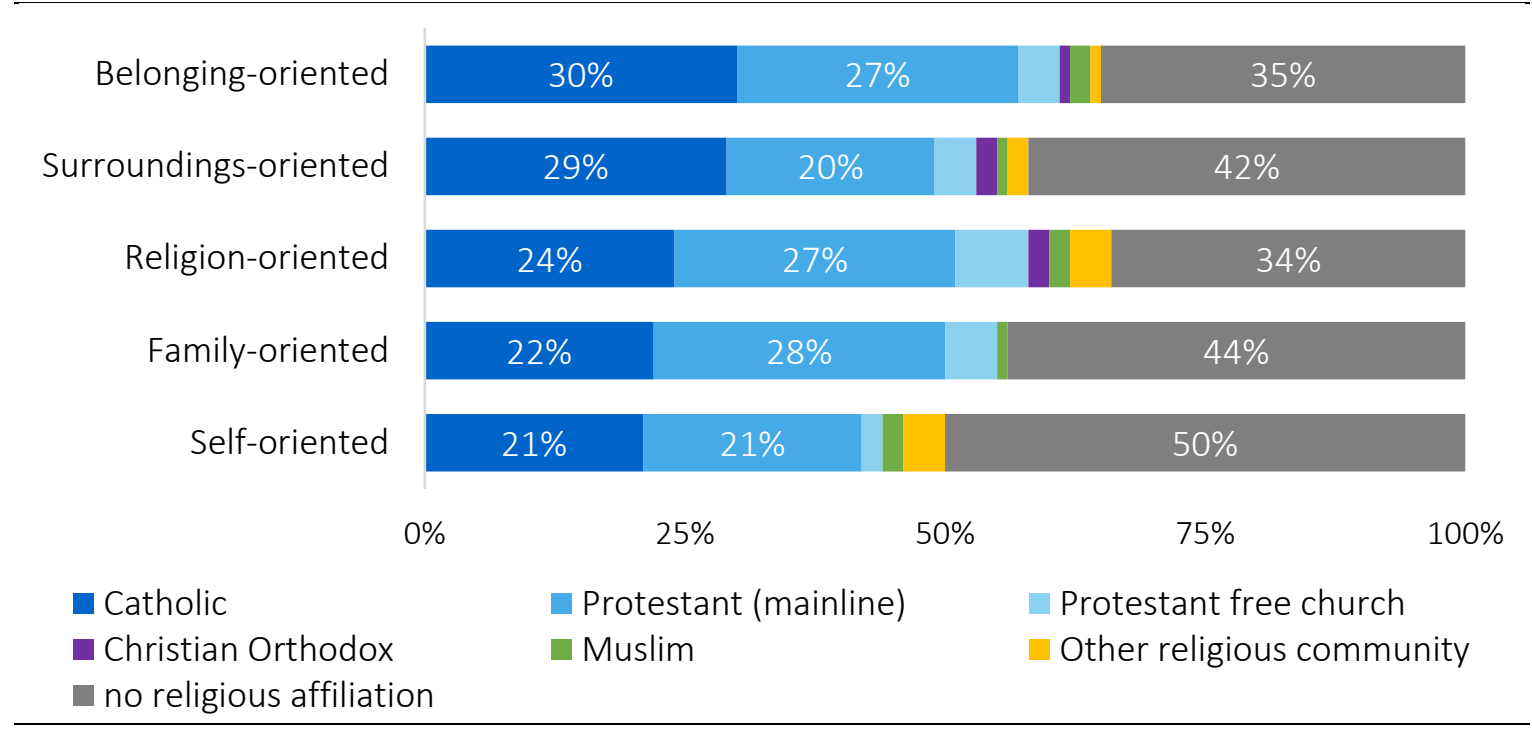

Source: KONID Survey DE 2019 / Figure: KONID-Team

Figure 7.4: Religious Affiliation within the Five Configurations in Switzerland

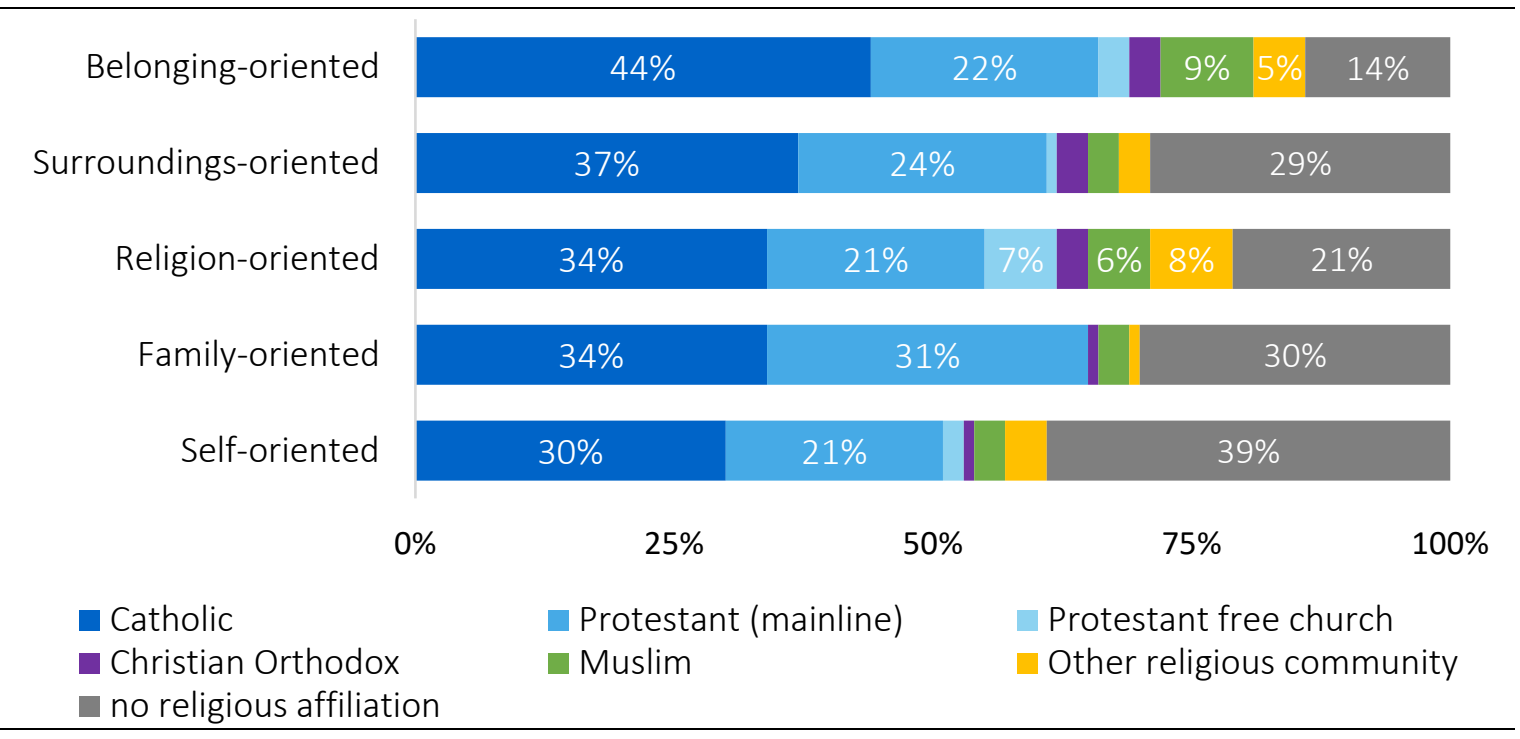

Source: KONID Survey CH 2019 / Figure: KONID-Team

In Switzerland, most people with a religious affiliation are also found among the belonging-oriented. Proportionally, however, they are followed first by the family-oriented and only then by the religion-oriented. As in Germany, members of free churches are particularly strongly represented among the religion-oriented. Muslims are placed above average among the belonging-oriented, and also make up a larger proportion among the religion-oriented. Unlike in Germany, they are not overrepresented among the self-oriented. As in Germany, people without a religious affiliation are strongly overrepresented among the self-oriented in Switzerland. Regarding the individual religiosity of the respondents, the great majority of highly-religious people in both countries are found among the religion-oriented, followed by the belonging-oriented. The non-religious in Switzerland are overrepresented among the self-oriented and the family-oriented. In Germany, they are found in almost equal measure among the self-oriented and the surroundings-oriented. As a result, it becomes evident that the differentiation of the five configurations according to religious variables 
leads more to country-specific findings than to general conclusions. Therefore, further investigations have to look at the country-specific patterns to assess their scope and relevance.

Figure 7.5: Location of Configurations in Terms of Religion and Marital Status in Germany

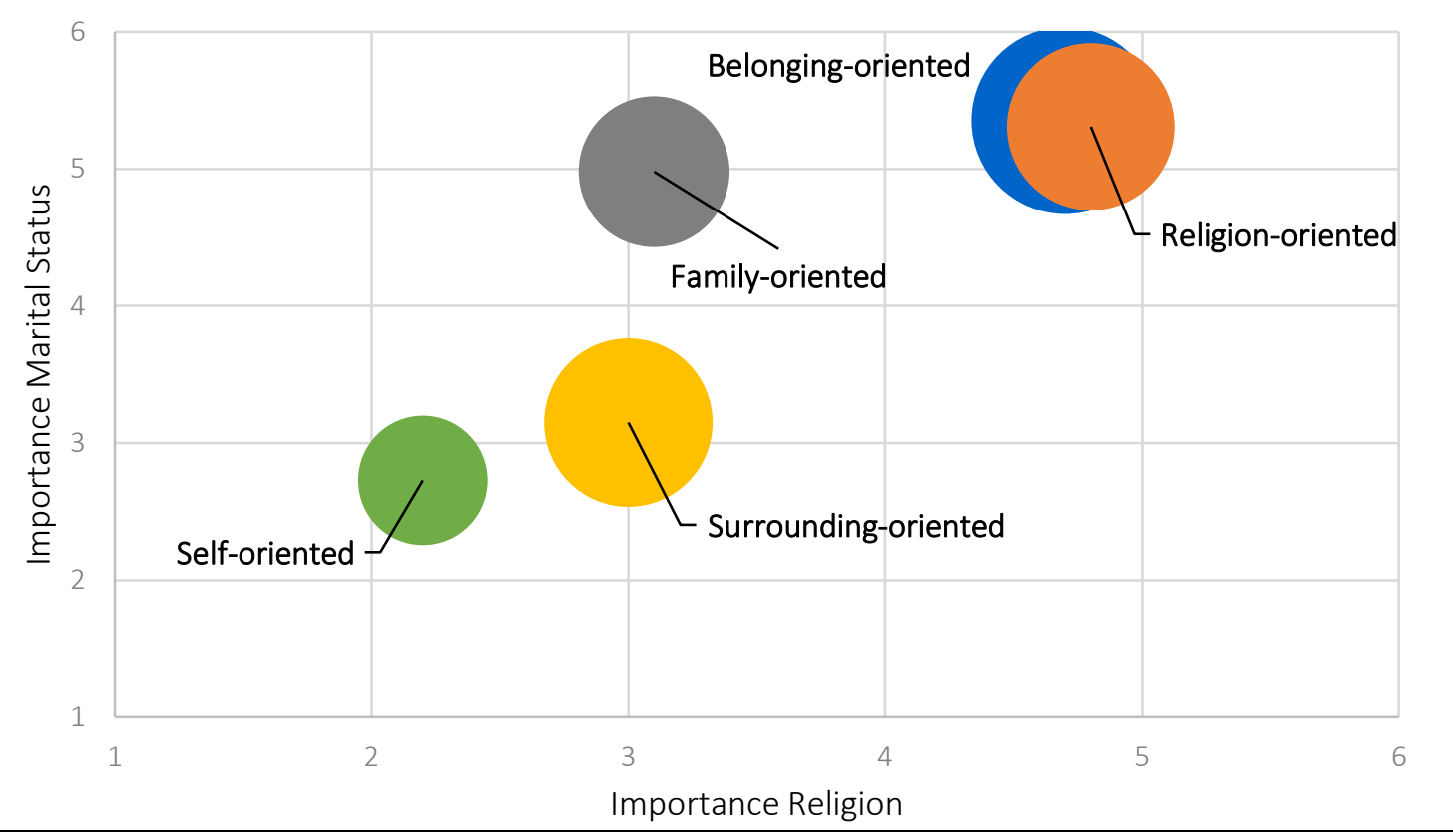

Source: KONID Survey DE 2019 / Figure: KONID-Team

Figure 7.6: Location of Configurations in Terms of Religion and Marital Status in Switzerland

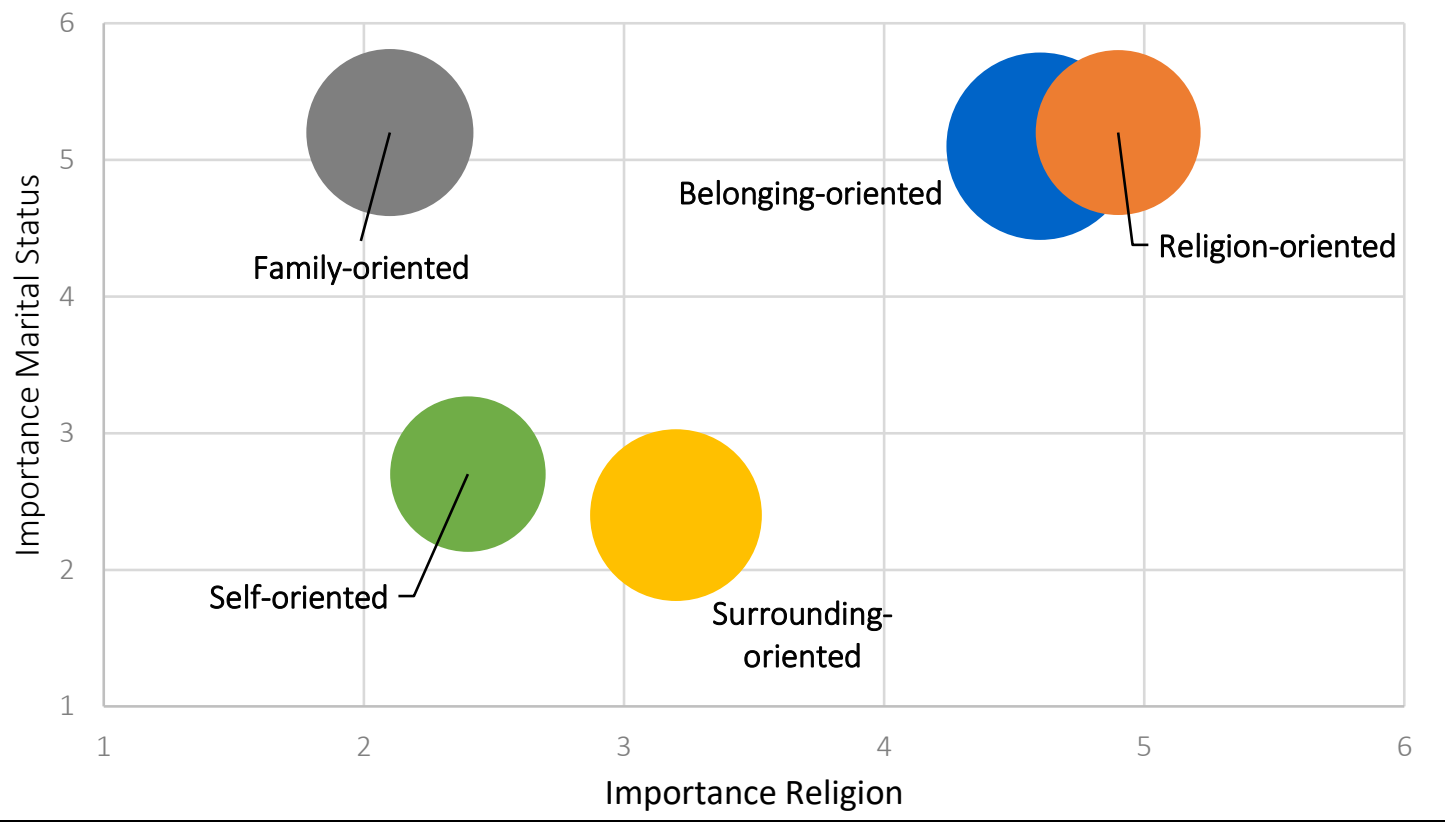

Source: KONID Survey CH 2019 / Figure: KONID-Team

The most interesting result from our cluster analysis becomes visible on another level of society. Indeed, the five configurations of social identities - presented here for the first time - yield a surprising finding at the macro level: the social identity 'religion' structures all five configurations of 
social identities to a very considerable extent, even though, as shown above, it is only of secondary importance at the level of individuals.

\section{Figure 7.7: Location of Configurations in Terms of Religion and Nation in Germany}

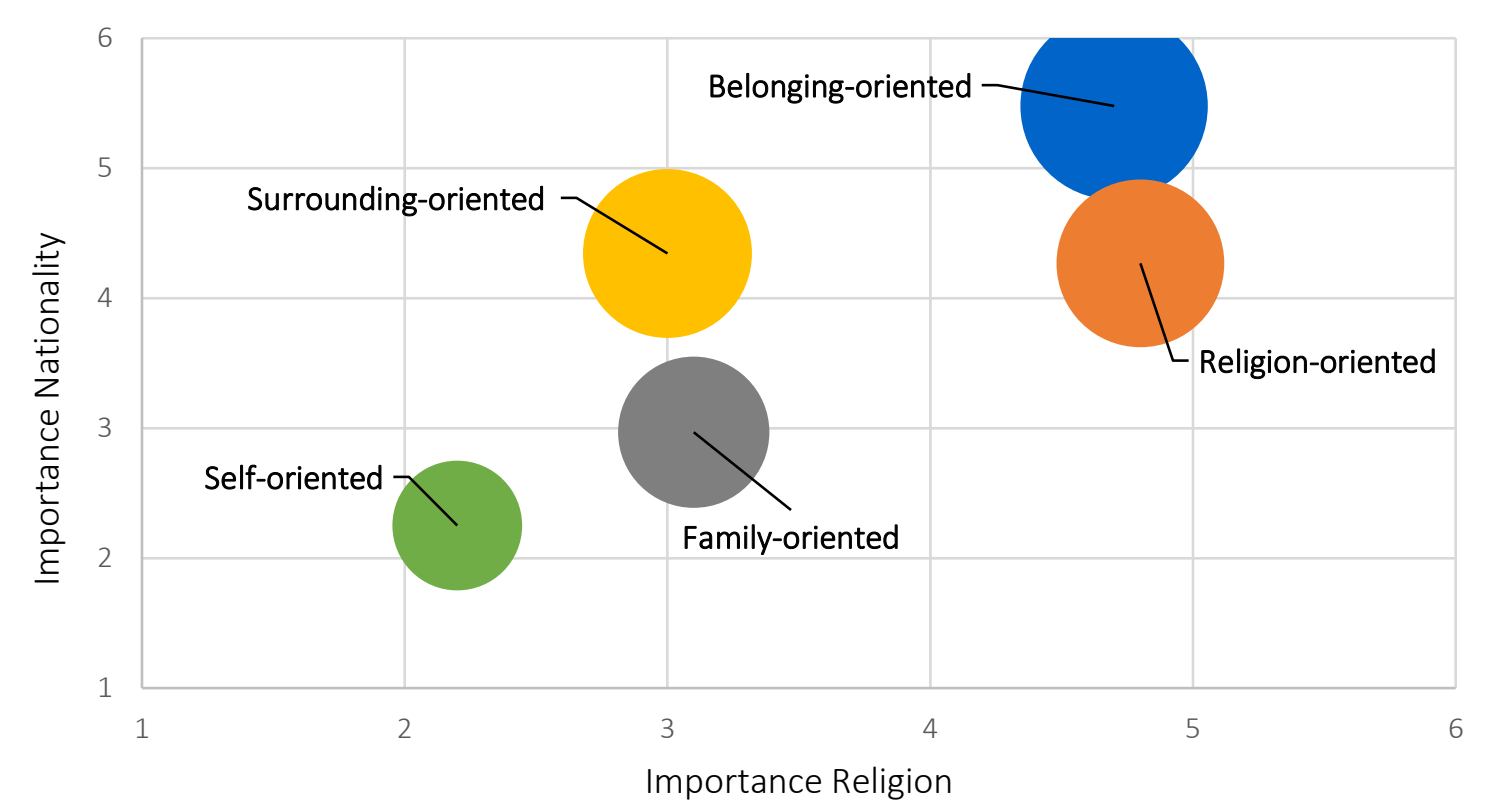

Source: KONID Survey DE 2019 / Figure: KONID-Team

Figure 7.8: Location of Configurations in Terms of Religion and Nation in Switzerland

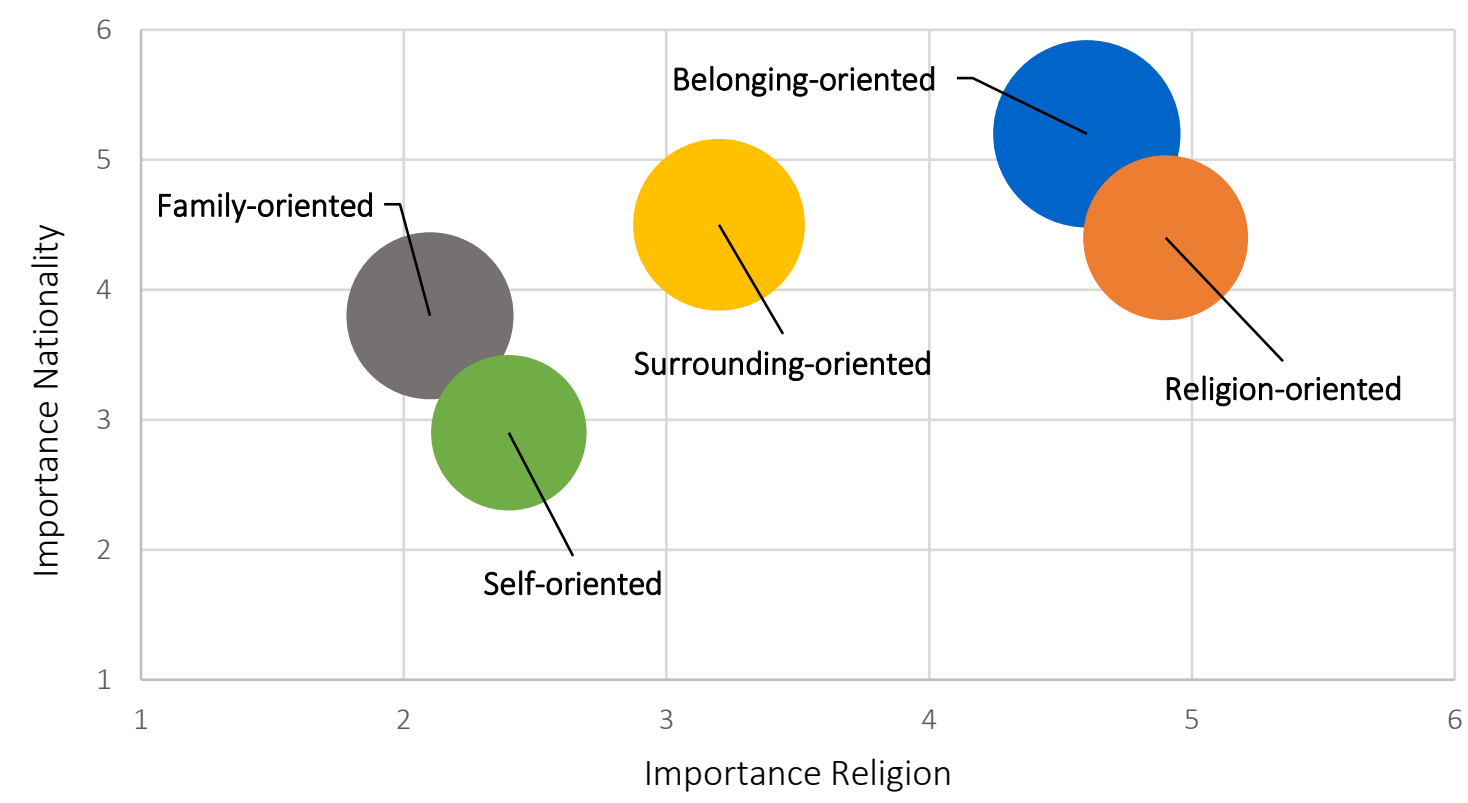

Source: KONID Survey CH 2019 / Figure: KONID-Team

This structuring effect of religion in the multitude of social identities can be illustrated by positioning the five configurations identified with their respective population proportions in a two-dimensional scatter diagram. This is done along the mean values of the configurations for the social identities religion and marital status (Figs. 7.5 and 7.6), and religion and nation (Figs. 7.7 and 7.8). The differentiating effect of religion is clearly visible in both representations. When comparing the importance of marital status, it is evident that religion separates the family-oriented from the self- 
oriented. In this diagram, the surroundings-oriented occupy a middle position on the religion axis. However, they are similar to the self-oriented in terms of the low significance of marital status.

The structuring effect of the social identity 'religion' also becomes apparent when looking at the position of the configurations according to the importance of the social identities 'religion' and 'nationality'. Above all, the importance of the social identity 'religion' separates the belonging-oriented and the religion-oriented from the other three configurations. This is similar to the first comparison with marital status. The surroundings-oriented also occupy a middle position in both respects: they consider their national affiliation to be quite important, and their social identity 'religion' to be rather unimportant. To the family oriented, both social identities are rather unimportant. In this case, religion ranks even lower in Switzerland than in Germany. This corresponds to the expectation that comes with the above description of this configuration. Among the self-oriented, the importance of the nation has the lowest scores in both countries, but religion is almost as unimportant.

The patterns differ somewhat between the two countries. In particular, the mean values of the five configurations for the importance of the nation are closer together in Switzerland. In Germany, the social identity nationality is unimportant for the self-oriented, but important for the belonging-oriented - with a clear tendency to "extremely important". Thus, in a country comparison, the configurations rate nationality very differently.

This finding is surprising if we recall that nationality, religion or denomination, and social class were the most important collective identities of the industrial age. ${ }^{48}$ Despite the increasing complexity of the construction of social identities, the KONID data show that religion and nationality are structuring variables in the configurations identified here. 


\section{Conclusion}

Social identities are an important part of a person's life. They are often a powerful resource for living together. They play a role in the discourses and conflicts of plural civil societies. Social identities are ascriptions of group membership by the self and by others. These ascriptions are, or can be, associated with appreciation and a sense of belonging for the individual. The personal encounter with religion and other systems of meaning, as well as the possible anchoring of a person in corresponding groups and communities, count among those relationships from which people gain their self-image as social beings. Religion is obviously not the only source of social identity. Rather, one of the main features of the present time seems to be that social identities of all kinds can become the object of social conflict. This adds to the aspect that they can be the centre of personal orientation and lifestyle. The revaluation of religious identities in the public sphere can be seen as perhaps the most prominent expression of the growing social importance of social identities.

The research project "Configurations of Individual and Collective Religious Identities and their Potential for Civil Society (KONID)", funded by the DFG and the SNF, investigates the significance of religious affiliations and attributions to religious groups with regard to individuals as well as in society and its groups. The project aims to analyse and explain the effects of religious identities for living together and social cohesion in a differentiated manner. For that purpose, the KONID Survey 2019 measures the importance of religion for social identities. It is a multi-thematic, country-comparative representative survey of the population in Germany and Switzerland aged 16 and older, with special attention to Muslim minorities.

The KONID Survey 2019, analysed in this report, examines 21 possible social identities. The aim of the initial analysis was threefold. First, to determine the importance of the social identity 'religion' for the individual. Second, to discover the extent to which religious identities polarise and unite people and groups in civil society and the political sphere. Third, to find out whether distinguishable configurations of social identities still exist within the diversity of possible social identities in complex societies, i.e. regularities in their occurrence and their combinations.

The KONID Survey 2019 reveals that:

Religion is a factor that shapes and structures social identity in Germany and Switzerland. For many people, their religious affiliation is relevant as a social identity. In Germany, 57\% of the population consider the social identity 'religion' as important. In Switzerland, the same goes for 50\% of the population. For $20 \%$ of the population in Germany, the social identity 'religion' is even "extremely important", the same applies to $13 \%$ in Switzerland. Overall, about half of the population consider their religious affiliation, or the fact that they have no religious affiliation, to be an important social identity. In a country comparison, respondents in Germany rated their religious identity as important somewhat more often than respondents in Switzerland. However, the differences are not that significant, and the basic structure is quite similar in both countries. They also share a certain degree of polarisation with regard to religion as a social identity: those people who consider religion to be "extremely important" for their social identity are contrasted with about $15 \%$ who regard the social identity 'religion' as "completely unimportant" in their lives. However, religion is not the most important social identity in people's self-image in either country. Above all, family membership and belonging to a circle of friends are far more important than religion. Furthermore, it is striking how important civic engagement is for the self-image of those who assume responsibility for other people in civil society and take on tasks in associations, organisations, and movements. 
The frequently asked question whether religion and religious identities tend to unite or divide society cannot be answered with a simple "yes" or "no". Religion is ambivalent in this regard. The KONID Survey shows that, like other social identities, the social identity 'religion' can act as a divisive and exclusionary social identity. Respondents in both countries report experiences of discrimination based on their religious identity. At the same time, however, they themselves are willing to use religion as a marker to create social distance.

Experiences of discrimination are generally moderate in Switzerland and Germany, but certain groups are more affected than others. 56\% of Muslims in Switzerland, and 50\% of Muslims in Germany state that they experience discrimination on the basis of their religious affiliation "rarely", "often" or "very often". Furthermore, our data show that this discrimination stems more from the stereotype "Muslim" than from the specific denominational school such as Sunnism or Alevism. However, experiences of discrimination on the basis of the social identity 'religion' are not limited to Muslims, with 69\% of members of free churches in Switzerland reporting the same experiences, and $48 \%$ of the Orthodox Christians in Germany. In both countries, about $20 \%$ of those without a religious affiliation say that they have been discriminated against because of their non-affiliation. In general, however, religion is not the most common reason for discrimination, but rather in both countries gender - in Switzerland even more so than in Germany (42\% to 33\%).

There is a widespread willingness among people to consider their own religious identity as a criterion for demarcation. In both countries, almost one in five people without a religious affiliation rule out marrying someone who belongs to a religion. A good quarter of Christians would not marry a non-Christian. About $40 \%$ of Muslims would not marry a non-Muslim. The rate of rejection is even higher among members of free churches in Switzerland (53\%), but not in Germany (15\%).

Ideological-fundamentalist belief in the supremacy of one's own religion over the constitution and democracy is rare. The KONID Survey 2019 also investigated how respondents draw the line between democratic community and religious truth. Specifically, the questions are whether a person places religion before the constitution when there is a conflict, whether a person's own religion is the only ultimate political authority, and whether there is a basic willingness among people to assert their own religious convictions by violence. In principle, people in both countries widely reject all these points. People rarely claim the primacy of religion over the constitution. Nevertheless, there are splinter groups across the religious communities that agree with one or more of these statements. For example, many members of free churches in both countries say that their religion takes precedence over the constitution in cases of conflict. Moreover, 8\% of Muslims in Switzerland, and $17 \%$ of Muslims in Germany agree that they would be willing to assert their religion by violence. On the whole, it is mostly only small minorities within the religious groups that hold dogmatic or fundamentalist positions. Their size hardly corresponds to the generalised threat scenarios that prevail in the media and public debates in both countries, especially regarding "Islam". However, even more important and decisive is to understand that this phenomenon occurs across all religious denominations.

The politically relevant problem is to obtain a general view of dogmatic or fundamentalist positions that have a political tendency towards extremism. The task is to address them together with the religious communities and take preventive action. There are many reasons why these attitudes are more frequent among Muslim respondents than among those belonging to other religions. These reasons require further investigation. It should be noted, though, that extreme religious-political attitudes are not an exclusive problem of "Islam" as a religion. 
By individual religiosity and through religious affiliation, religion promotes civic engagement and thus civil society. At the heart of civil society, i.e. the intermediate, public sphere of social selforganisation between the state, the economy, culture/ religion and the private sphere, ${ }^{49}$ is the civic engagement of citizens. For both countries, the data of the KONID Survey 2019 show that religion is a pillar for volunteering, with religion operating at the structural level of organising such activities. Also, religion is conducive to voluntary work via the individual level of religiosity and through religious affiliation. Moreover, people who classify their social identity 'religion' as "important" or "extremely important" are more inclined to volunteer. In Germany, of those to whom religion is important as a social identity, around $60 \%$ do volunteer, while that figure in Switzerland is around $50 \%$. These figures are socially important, also because such civic engagement brings people into contact who would otherwise not meet in everyday life. Of those active in the area of religion, $71 \%$ of respondents in Germany, and 63\% in Switzerland report such contacts during their voluntary work. Religion contributes to bridging social capital, i.e. to the resources of social cohesion.

Contrary to the claims of Social Capital Theory, this link between religion and social capital is not consistently present in generalised trust. If there were a direct link, we might expect that the higher bridging social capital in Germany would be accompanied by a higher level of general trust in other people. However, this is not the case: people living in Switzerland generally trust their fellow citizens to a much higher degree.

For those who consider their religious identity to be important, interreligious dialogue is also important. The KONID Survey 2019 examined religion as a social identity not only in civil society, but also with regard to its supportive aspects in socio-political terms. Two points are to be emphasised here. Firstly, support for interreligious dialogue increases with the importance of the social identity 'religion'. In other words, someone who attaches importance to her or his religious identity also considers interreligious dialogue to be important. In Germany, this applies to $66 \%$ of the population, and in Switzerland to $60 \%$. Those to whom religion is important are, thus, aware of the fact that the diversity of religions requires mediation through exchange and dialogue. Moreover, they know that they can contribute to this. Support is strongest among religious minorities and particularly Muslim respondents. This shows the great potential for social dialogue. All members of society are called upon to take this potential seriously and take it up as part of the task of integrating a diverse society and thus strengthening social cohesion.

There is broad consensus on the right to religious freedom. Secondly, the potential for social dialogue that we have identified rests in both countries on an almost blanket consensus on the value of religious freedom for living together in society. In this way, too, religious diversity can unite society and promote social cohesion.

Some of our findings confirm previous research results. Until now, however, these results have often been scattered across different fields of research and various surveys, making it difficult to relate them to each other. The novelty of the KONID results stems from the sum of the parts of the multi-thematic representative survey. For the first time, it is possible to examine and evaluate comparatively the role of the social identity 'religion' in its manifold relations within complex pluralistic societies. The findings summarised so far show that this approach leads to nuanced assessments that also carry political weight. The data make it possible to counteract simplifying and generalising judgments about religion or certain religious communities. Further evaluations that go beyond the predominantly descriptive findings presented here will follow in the coming years.

A particular new insight gained from the initial evaluation is the connection identified between religious identity at the individual and the societal level. If the focus of analysis switches from the 
level of individuals and groups to the macro level of society, new patterns are indeed revealed in the diversity of social identities for both Germany and Switzerland. These patterns are even very similar in both countries.

In Germany and Switzerland, there are five configurations of social identities: the belonging-oriented, the surroundings-oriented, the religion-oriented, the family-oriented, and the self-oriented. Based on the KONID Survey 2019, we identified these five configurations of social identities for both countries. They group people with similar orientations regarding the importance of their social identities. In Germany as in Switzerland, there are belonging-oriented, surroundings-oriented, religion-oriented, family-oriented, and self-oriented. The belonging-oriented generally attach great importance to their social identities, meaning that the social identity 'religion' is also important for them. The surroundings-oriented also take the whole range of social identities into account, but generally consider social identities to be less important for their self-image. Accounting for $19 \%$ in Germany and $21 \%$ in Switzerland, the religion-oriented clearly foreground the religious identity. Particularly important for the self-image of the family-oriented are family and friends, with religion playing a rather subordinate role; this applies in Germany even more than in Switzerland. For the self-oriented, social identities of all kinds are of minor importance. All five configurations can be found among all religious communities and those without a religious affiliation. The proportions vary in detail. Once again, it is evident that religious communities are by no means homogeneous entities in themselves, but have to varying degree their share in today's plural and complex democratic societies. This finding is decisive.

Finally, the five configurations lead to a surprising finding for the macro level.

Although the social identity 'religion' is on average only of moderate importance at the individual level, it structures all five configurations of social identity to a great extent at the level of society. Perhaps this can be seen as an empirical indicator of the emergent properties of social systems as postulated by Systems Theory. Societal phenomena as a whole arise not only from simple aggregation processes of characteristics of (interviewed) individuals. They are also based on effects that only occur through the combination of a multitude of properties. Thus, they acquire an independent quality and importance. The structuring role of religion for the configuration of social identities at the level of society is therefore a crucial finding that is also relevant for social theory. Despite the increasing complexity of the construction of social identities for the individual, religion in Germany and Switzerland is a factor in society that structures social identities consistently. 


\section{Notes}

${ }^{1}$ Cf. Putnam, Bowling Alone; Putnam/ Campbell, Grace; Traunmüller, Religion. - The references in this report on the first results of the KONID Survey 2019 are limited to the most important intellectual impulses, basic scientific works, and selected further references. Therefore, they do not claim completeness.

${ }^{2}$ Cf. Decker/ Kiess/ Brähler, Mitte; Pollack et al., Grenzen; Koopmans, Assimilation; Zick/ Küpper, Religion and Prejudice; Zick/ Küpper/ Hövermann, Abwertung; Zick/ Küpper/ Berghan, Verlorene Mitte.

${ }^{3}$ Cf. Decker/ Kiess/ Brähler, Mitte; Pollack et al., Grenzen; Koopmans, Assimilation; Zick/ Küpper/ Hövermann, Abwertung.

${ }^{4}$ Tajfel, Introduction, p. 2 (emphasis in the original).

${ }^{5}$ Both surveys were conducted in mixed mode with computer-assisted telephone interviews (CATI) and internet-supported self-assessment via an online survey tool (CAWI). Differences in the survey procedures resulted primarily from the type of sampling. In Germany, the ADM-frame was used for the main survey and an onomastic sampling procedure was used for the Muslim sample. In Switzerland, a stratified representative sample was drawn. It is based on the sampling frame for person- and household-surveys SRHP, developed by the Federal Statistical Office (FSO).

${ }^{6}$ For the KONID Survey Switzerland, a stratified random sample was drawn from the sample framework (SRHP). In Germany, the survey is based on the ADM-frame. The response rate was $23.7 \%$ in Switzerland and $10.6 \%$ in Germany (CATI). Response rates have generally declined in recent years. The crucial question is whether the non-responses are random or systematic. Where identifiable and possible, such systematic biases were corrected on the basis of known demographic characteristics. A further weighting was deliberately excluded, as this in turn could have resulted in bias.

${ }^{7}$ Cf. Haller/ Müller; Merkmale; Müller, Identitätsforschung.

${ }^{8}$ Cf. Danaci, Macht, 50; Liedhegener, Identitäten.

${ }^{9}$ Cf. Charim, Ich und die Anderen; Delitz, Kollektive Identitäten; Emcke, Kollektive Identitäten; Pickel/ Pickel, Migration; Fukuyama, Identity.

${ }^{10}$ We are aware that the identity of a person is not exclusively determined by her or his social identity. Indeed, respondents assess the importance of their social identity very differently, as will be shown (see 7 below). Knowing that the identity of a person is also shaped by character traits and by her or his self-image as an individual, the KONID Survey 2019 also contains established questions for measuring personality. These are reserved for later analysis. Cf. Müller, Identitätsforschung, for a summary of the socio-psychological theory debate.

${ }^{11}$ Question: "We all have a range of different characteristics that make us who we are as a person. Some of these are very important to us, others are not very important. How is it for you? How important are the following characteristics?" The answer options were: being a Christian; being a Jew; being a Muslim; being a Buddhist; being a Hindu; being a follower of your own religion; being a person without any religion. Answer options: completely unimportant; not important; rather unimportant; rather important; important; extremely important.

12 There is no agreement on the question of whether the Alevis should be regarded as a group within Islam or as an independent religion. In this project, we have located the Alevis within Islam. The reason for this is that those who stated "Islam" as their religious affiliation could subsequently select "Alevis" among the various denominations.

${ }^{13}$ This scale was developed and implemented primarily by Stefan Huber as part of the first wave of the Religion Monitor initiated by the Bertelsmann Foundation. For its construction, see Huber, Centrality; Huber, Religion Monitor; Huber/ Huber, Centrality.

${ }^{14}$ To facilitate understanding, we follow the original naming of the three categories that were formed along with the index, as used in the Religion Monitor 2008. Objectively it would also be justified to speak of the "(highly) religious", the "more or less religious", and the "non-religious", because in the middle category there is a broader spectrum of forms of religiosity. The Bertelsmann Foundation's Religion Monitor for 2013 therefore speaks of "highly religious", "medium religious" and "non-religious". Cf. Pickel, Religion Monitor, p. 16.

${ }^{15}$ Cf. Keller, World Views; Voas, Afterword.

${ }^{16} \mathrm{Cf}$. Davie, Religion, and the phenomenon of "believing without belonging" described there.

17 The importance of the social identity 'religion' correlates significantly with religiosity among persons with a religious affiliation in Germany $(r=.56, p=.00, n=1336)$ and in Switzerland $(r=.61, p=.00, n=2099)$, both of which are strong effects. In contrast, there is no correlation among persons without a religious affiliation, either in Germany ( $r=-.09, p=.01, n=859)$ or in Switzerland ( $r=-.01, p=.73, n=727)$. 
${ }^{18}$ Cf. Knoblauch, Religion.

${ }^{19} \mathrm{Cf}$. Jenkins, Social Identity.

${ }^{20} \mathrm{Cf}$. Fix/ Fix, Kirche, for reference to the literature on the development of Western welfare states.

${ }^{21}$ Cf. e.g. Westle, Aspekte, pp. 464-466.

22 Systematic overview in Zick, Konflikttheorie.

${ }^{23} \mathrm{Cf}$. Nagel, Parallelgesellschaften.

${ }^{24}$ Gianni, Democracy; Mazzoleni, Populism; Pickel/ Yendell, Religion; Pollack et al., Grenzen.

${ }^{25} \mathrm{Cf}$. Stolz et al., Ich-Gesellschaft, for Switzerland.

${ }^{26}$ In Switzerland, the "Frauen*streik" (women's strike), which took place on 14 June 2019, fell within the survey period. The strike raised public awareness of the issue and may therefore have increased the scores. On the other hand, the women's strike itself could also be a symptom of a stronger experience of discrimination in Switzerland.

${ }^{27}$ For the KONID Survey, persons of various religious affiliations were interviewed. However, for small groups, no reliable conclusions can be drawn for the population. This would overstretch the survey instrument. In this case, this limitation applies to Jews, Hindus and Buddhists, among other groups. Cf. Tab. 3.1a and b, comments.

${ }^{28}$ For the social distances measured here, there are confirming values in the Bertelsmann Religion Monitor 2017. Cf. Pickel, Weltanschauliche Vielfalt, p. 78.

${ }^{29}$ Cf. Stepan, Religion; Bielefeldt, Streit.

30 The KONID Survey 2019 offers high-quality data for such analysis due to its high case numbers from the special samples of Muslim respondents.

${ }^{31}$ Gordon Allport sums this up in his prominent work from 1954: religion "makes and unmakes prejudice". Allport, Nature, p. 444.

${ }^{32}$ Cf. Nagel, Parallelgesellschaft.

${ }^{33}$ Cf. Putnam, Democracy; Putnam, Bowling Alone.

${ }^{34} \mathrm{Cf}$. Liedhegener, Model, for a description of this indication.

${ }^{35} \mathrm{Cf}$. Gensicke/ Geiss, Hauptbericht.

${ }^{36}$ Cf. Liedhegener, Säkularisierung; Pickle, Säkularisierung; Pollack/ Rosta, Religion; Stolz et al., Ich-Gesellschaft.

${ }^{37}$ As the contingency table analysis shows, religiosity and commitment are related in Germany and Switzerland (Germany: chi-square $(2)=54.01, p=.000, n=2294$; Switzerland: chi-square $(2)=51.55, p=.00, n=$ 2888). There is at least a weak correlation in both countries (Germany: contingency coefficient $=.152, p$ $=.000$; Cramér's $V=.154, p=.000$; Switzerland: contingency coefficient $=.132, p=.000$; Cramér's $V=.134$, $p=.000)$.

${ }^{38}$ In Germany and Switzerland, the orientation as religiously conservative or religiously liberal and commitment are not related (Germany: chi-square $(1)=1.65, p=.198, n=1496$; Switzerland: chi-square $(1)=1.64$, $p=.201, n=2554)$.

${ }^{39} \mathrm{Cf}$. Liedhegener, Unterschied, on religion as motivation of voluntary commitment.

${ }^{40}$ In Germany and Switzerland, the importance of the social identity 'religion' and civic engagement are indeed related (Germany: chi-square (3) = 19.77, $p=.000, n=2240$; Switzerland: chi-square $(3)=13.36, p$ $=.004, n=2892$ ). However, the correlations are very weak and, thus, in practice not too relevant (Germany: contingency coefficient $=.094, p=.000$; Cramér's $V=.094, p=.000$; Switzerland: contingency coefficient $=.068, p=.004 ;$ Cramér's $V=.068, p=.004)$.

${ }^{41}$ In Germany and Switzerland, religious affiliation and civic engagement are related (Germany: chi-square $(10)=25.36, p=.005, n=2312$; Switzerland: chi-square $(10)=85.07, p=.000, n=2970)$. In both countries, there is a weak correlation (Germany: contingency coefficient $=.104, p=.005$; Cramér's $V=.105, p=.000$; Switzerland: contingency coefficient $=.167, p=.000$; Cramér's $V=.169, p=.004$ ).

${ }^{42}$ Cf. Freitag, Kapital; Gensicke, Hauptbericht.

${ }^{43}$ Cf. Freitag, Kapital; Pickel, Religionsmonitor; Pickel, Weltanschauliche Vielfalt.

${ }^{44}$ In Germany, this question was only given to those respondents with a formal religious affiliation. In Switzerland, all respondents were given the question. To ensure comparability, we present the following results for those with a religious affiliation only.

${ }^{45} \mathrm{Cf}$. Baumann/Tunger-Zanetti, Diversity; Vopel/ El-Menouar, Religionsmonitor.

${ }^{46} \mathrm{Cf}$. Zulehner, Verbuntung.

${ }^{47}$ Both cluster analyses were calculated with the statistical software package SPSS. The 21 social identities served as a basis for the calculation. We adopted the same approach of analysis for both countries. To determine the number of clusters, we first identified and excluded outliers by means of a hierarchical cluster 
analysis (single linkage with squared Euclidean distance). Subsequently, five successive hierarchical cluster analyses (complete linkage with squared Euclidean distance), each with a different random case sequence, were calculated and analysed with regard to variance minimisation. For the cluster solutions (number of clusters), the respective cluster centres were calculated by way of a mean value procedure. These were then imported into a k-means cluster analysis to assign all cases to clusters (classification and iteration, without moving means). From the analysis carried out with these data emerged the five-cluster-solution described. For the final cluster assignment, another 150 hierarchical cluster analyses were calculated as described above, each with a different random case sequence, and the cluster centres were determined for the final kmeans cluster analysis. Finally, this resulted in the solution described. Further analysis and more detailed documentation for the calculation of the cluster analysis are reserved for subsequent publications. Anastas Odermatt (University of Lucerne) will be happy to answer any questions. On the statistical procedure, see Backhaus, Multivariate Analysemethoden; Bühl, SPSS. A similar procedure for clustering is applied in: Pew, Categorizing Americans.

${ }^{48} \mathrm{Cf}$. Lipset/ Rokkan, Cleavage Structures.

${ }^{49}$ For a description of this indication, see Liedhegener, Model. 


\section{References}

Allport, Gordon, The Nature of Prejudice, Boston, MA 1954.

Backhaus, Klaus / Erichson, Bernd / Plinke, Wulff / Weiber, Rolf, Multivariate Analysemethoden. Eine anwendungsorientierte Einführung, Berlin 2016.

Baumann, Martin/ Tunger-Zanetti, Andreas, Constructing and Representing the New Religious Diversity with Old Classifications: 'World Religions' as an Excluding Category in Interreligious Dialogue in Switzerland, in: Kühle, Lene/ Hoverd, William/ Borup, Jorn (ed.), The Critical Analysis of Religious Diversity (= International Studies in Religion and Society, Bd.32) Leiden - Boston, MS 2018, 180-207.

Bielefeldt, Heiner, Streit um die Religionsfreiheit. Aktuelle Facetten der internationalen Debatte, in: Arens, Edmund (ed.), Integration durch Religion? Geschichtliche Befunde, gesellschaftliche Analysen, rechtliche Perspektiven (= Religion - Wirtschaft - Politik, Bd.10) Baden-Baden - Zürich 2014, 230-255.

Bühl, Achim, SPSS. Einführung in die moderne Datenanalyse ab SPSS 25, Hallbergmoos 2019.

Charim, Isolde, Ich und die Anderen. Wie die neue Pluralisierung uns alle verändert, Wien 2018.

Danaci, Deniz, Die Macht sozialer Identitäten. Einstellungen und Abstimmungsverhalten gegenüber Minderheiten in der Schweiz (= Politik und Demokratie in den kleineren Ländern Europas, Bd.3) Baden-Baden 2012.

Davie, Grace, Religion in Britain since 1945. Believing without Belonging, Oxford 1994.

Decker, Oliver/ Kiess, Johannes/Brähler, Elmar, Enthemmte Mitte. Autoritäre und rechtsextreme Einstellung in Deutschland. Die Leipziger "Mitte"-Studie 2016, 2. Aufl., Gießen 2016.

Delitz, Heike, Kollektive Identitäten (= Einsichten. Themen der Soziologie) Bielefeld 2018.

Emcke, Carolin, Kollektive Identitäten: Sozialphilosophische Grundlagen, Frankfurt a.M. 2018.

Fix, Birgit/ Fix, Elisabeth, Kirche und Wohlfahrtsstaat. Soziale Arbeit kirchlicher Wohlfahrtsorganisationen im westeuropäischen Vergleich, Freiburg i.Br. 2005.

Freitag, Markus (ed.), Das soziale Kapital der Schweiz, unter Mitarbeit von Kathrin Ackermann a.o. (= Politik und Gesellschaft in der Schweiz) Zürich 2014.

Fukuyama, Francis, Identity, Contemporary Identity Politics and the Struggle for Recognition, London 2018.

Gensicke, Thomas/ Geiss, Sabine, Hauptbericht des Freiwilligensurveys 2009. Engagementpolitik, Zivilgesellschaft, soziales Kapital und freiwilliges Engagement in Deutschland 1999 - 2004 2009. Ergebnisse der repräsentativen Trenderhebung zu Ehrenamt, Freiwilligenarbeit und Bürgerschaftlichem Engagement, durchgeführt in Auftrag vom Bundesministerium für Familie, Senioren, Frauen und Jugend, vorgelegt von TNS Infratest Sozialforschung, unterstützt von BertelsmannStiftung und Generali ZukunftsFonds, München 2010 (pdf-version).

Gianni, Matteo, Protecting Democracy, Misrecognising Muslims? An Assessment of Swiss Integration Policy, in: Behloul, Samuel M./ Leuenberger, Susanne/ Tunger-Zanetti, Andreas (ed.), 
Debating Islam. Negotiating Religion, Europe, and the Self (= global local Islam) Bielefeld 2013, 313-330.

Haller, Max/ Müller, Bernadette, Merkmale der Persönlichkeit und Identität in Bevölkerungsumfragen. Ansätze zu ihrer Operationalisierung und Verortung als Erklärungsvariable für Lebenszufriedenheit, in: ZUMA-Nachrichten 30(2006) H.59, 9-41.

Huber, Stefan, Zentralität und Inhalt. Ein neues multidimensionales Messmodell der Religiosität, Leske + Budrich, Opladen 2003.

Huber, Stefan, Der Religionsmonitor 2008: Strukturierende Prinzipien, operationale Konstrukte, Auswertungsstrategien, in: BertelsmannStiftung (ed.), Woran glaubt die Welt? Analysen und Kommentare zum Religionsmonitor 2008, Verlag BertelsmannStiftung, Gütersloh 2009, 17-52.

Huber, Stefan / Huber, Odilo W., The Centrality of Religiosity Scale (CRS), in: Religions 3 (2012), 710-724.

Jenkins, Richard, Social Identity, 3. edition., Oxon, New York 2004.

Keller, Barbara et al., Profiling Atheist World Views in Different Cultural Contexts. Developmental Trajectories and Accounts, in: Psychology of Religion and Spirituality 10(2018) H.3, 229-243.

Knoblauch, Hubert, Populäre Religion. Auf dem Weg in eine spirituelle Gesellschaft, Frankfurt a.M. 2009.

Koopmans, Ruud, Assimilation oder Multikulturalismus? Bedingungen gelungener Integration, Münster 2017

Küpper, Beate; Zick, Andreas, Religion and Prejudice in Europe. New empirical findings. Dossier for the Network of European Foundations - Initiative for Religion and Democracy in Europe. London 2010.

Liedhegener, Antonius, Religiöse Identitäten als Problem wechselseitiger Identifizierungen und Kategorisierungen. Aktuelle theoretische Konzepte und Fragen ihrer Operationalisierung in der empirischen Religionsforschung, in: Werkner, Ines-Jacqueline/ Hidalgo, Oliver (ed.), Religiöse Identitäten in politischen Konflikten (= Politik und Religion) Wiesbaden 2016, 65-82.

Liedhegener, Antonius, Religion in Zivilgesellschaft, Öffentlichkeit und Politik in demokratischen politischen Systemen. Sechs Fallbeispiele und ein heuristisches Modell der empirischen politischen Theorie, in: Könemann, Judith/Wendel, Saskia (ed.), Religion, Öffentlichkeit, Moderne. Transdisziplinäre Perspektiven, unter Mitarbeit von Martin Breul, Bielefeld 2016, 93-127.

Liedhegener, Antonius, Säkularisierung als Entkirchlichung. Trends und Konjunkturen in Deutschland von der Mitte des 19. Jahrhunderts bis zur Gegenwart, in: Gabriel, Karl/ Gärtner, Christel/ Pollack, Detlef (ed.), Umstrittene Säkularisierung. Soziologische und historische Analysen zur Differenzierung von Religion und Politik, 2. durchges. und um ein Reg. erg. Aufl., Berlin 2014, 481-531.

Liedhegener, Antonius, Ein kleiner, aber feiner Unterschied. Religion, zivilgesellschaftliches Engagement und soziale Integration in der Schweiz, in: Arens, Edmund (ed.), Integrationspotenziale von Religion und Zivilgesellschaft. Theoretische und empirische Befunde (= Religion - Wirtschaft - Politik, Bd.14) Baden-Baden - Zürich 2016, 121-181. 
Lipset, Seymour Martin/ Rokkan, Stein, Cleavage Structures, Party Systems, and Voter Alignments: An Introduction, in: Dies. (ed.), Party Systems and Voter Alignments. Cross-National Perspectives, New York 1967, 1-64.

Mazzoleni, Oscar, Populism and Islam in Switzerland. The Role of the Swiss People's Party, in: Marzouki, Nadia/ McDonnell, Duncan/ Roy, Olivier (ed.), Saving the People. How Populists Hijack Religion, London 2016, 47-60 und 212-215.

Müller, Bernadette, Empirische Identitätsforschung. Personale, soziale und kulturelle Dimensionen der Selbstverortung, Wiesbaden 2011.

Nagel, Alexander K. (ed.), Diesseits der Parallelgesellschaft. Neuere Studien zu religiösen Migrantengemeinden in Deutschland, Bielefeld 2013.

Pew Research Center, The Religious Typology: A New Way to Categorize Americans by Religion, Washington, DC 2018 (http://www.pewforum.org/2018/08/29/the religious typology/ accessed on 16.10.2019).

Pickel, Gert, Säkularisierung, Individualisierung oder Marktmodell? Religiosität und ihre Erklärungsfaktoren im europäischen Vergleich, in: KZfSS 62(2010) 219-245.

Pickel, Gert, Religionsmonitor. Verstehen was verbindet. Religiosität im internationalen Vergleich, Gütersloh 2013.

Pickel, Gert, Weltanschauliche Vielfalt und Demokratie. Wie sich religiöse Pluralität auf die politische Kultur auswirkt, Gütersloh 2019.

Pickel, Gert/ Pickel, Susanne, Migration als Gefahr für die politische Kultur? Kollektive Identitäten und Religionszugehörigkeit als Herausforderung demokratischer Gemeinschaften, in: Pickel, Gert/ Röder, Antje/ Blätte, Andreas (ed.), Migration und Integration als politische Herausforderung - Vergleichende Analysen zu politisch-kulturellen Voraussetzungen der Migrationspolitik und Reaktionen (= Zeitschrift für Vergleichende Politikwissenschaft. Special Issue 1-18) Wiesbaden 2018, 297-320.

Pickel, Gert/ Yendell, Alexander, Religion als konfliktärer Faktor im Zusammenhang mit Rechtsextremismus, Muslimfeindschaft und AfD-Wahl, in: Decker, Oliver/ Brähler, Elmar (ed.), Flucht ins Autoritäre. Rechtsextreme Dynamiken in der Mitte der Gesellschaft. Die Leipziger Autoritarismus-Studie 2018, Gießen 2018, 217-242.

Pollack, Detlef et al., Grenzen der Toleranz. Wahrnehmung und Akzeptanz religiöser Vielfalt in Europa (= Veröffentlichungen der Sektion Religionssoziologie der Deutschen Gesellschaft für Soziologie) Wiesbaden 2014.

Pollack, Detlef/ Rosta, Gergely, Religion in der Moderne. Ein internationaler Vergleich (= Religion und Moderne, Bd.1) Frankfurt - New York 2015.

Putnam, Robert D., Bowling Alone. The Collapse and Revival of American Community, New York a.o. 2000.

Putnam, Robert D., Making Democracy Work. Civic Traditions in Italy, with Roberto Leonardi and Raffaella Y. Nanetti, Princeton 1993.

Putnam, Robert D./ Campbell, David E., American Grace. How Religion Divides and Unites US, with the Assistance of Shaylyn Roney Garrett, New York a.o. 2010. 
Stepan, Alfred, Religion, Democracy, and the "Twin Tolerations", in: Journal of Democracy 11(2000) H.4, 37-57.

Stolz, Jörg et al., Religion und Spiritualität in der Ich-Gesellschaft. Vier Gestalten des (Un-)Glaubens (= Publikationsreihe des Schweizerischen Pastoralsoziologischen Instituts) St. Gallen 2014.

Tajfel, Henri, Introduction, in: Tajfel, Henri (ed.), Social Identity and Intergroup Relations (= European Studies in Social Psychology) Cambridge 1982, 1-11.

Traunmüller, Richard, Religion und Sozialkapital. Ein doppelter Kulturvergleich, Wiesbaden 2012.

Voas, David, Afterword: Some reflections on numbers in the study of religion, in: DISKUS 16 (2014).

Vopel, Stephan/ El-Menouar, Yasemin, Religionsmonitor. Verstehen was verbindet. Sonderauswertung Islam 2015. Die wichtigsten Ergebnisse im Überblick, Gütersloh 2015.

Westle, Bettina, Aspekte Politischer Kultur im internationalen Vergleich - Legitimitätsvorstellungen und Legitimitätsurteile: Hierarchien und Muster politischer Unterstützung, in: Westle, Bettina/ Gabriel, Oscar W. (ed.), Politische Kultur. Eine Einführung (= Studienkurs Politikwissenschaft) Baden-Baden 2009, 452-528.

Zick, Andreas, Die Konflikttheorie der Theorie sozialer Identität, in: Bonacker, Thorsten (Hg.), Sozialwissenschaftliche Konflikttheorien. Eine Einführung (= Friedens- und Konfliktforschung, Bd.5) Opladen 2002, 409-427.

Zick, Andreas/ Küpper, Beate/ Berghan, Wilhelm, Verlorene Mitte - Feindselige Zustände. Rechtsextreme Einstellungen in Deutschland 2018/19, Bonn 2019.

Zick, Andreas/ Küpper, Beate/ Hövermann, Andreas, Die Abwertung der Anderen. Eine europäische Zustandsbeschreibung zu Intoleranz, Vorurteilen und Diskriminierung, ed. by Friedrich-EbertStiftung, Berlin 2011.

Zulehner, Paul M., Verbund. Kirchen im weltanschaulichen Pluralismus. Religion im Leben der Menschen 1970-2010, Ostfildern ${ }^{2} 2011$. 


\section{Acknowledgements}

This study would not have been possible without the help and support of many people. We would like to thank

- the DFG and the SNF and our reviewers for granting financial support, especially for the two representative surveys in Germany and Switzerland,

- the two survey institutes aproxima (Weimar) and DemoSCOPE (Adligenswil), and in particular those responsible for fieldwork, Juliane Lässig, Selina Recke (both Weimar), and Dr. Michael Buess (Lucerne),

- the colleagues Martin Baumann (Lucerne) and Alexander Nagel (Göttingen), and the colleagues Rebekka Rieser (Lucerne) and Arnela Balic (Göttingen) from our qualitative partner project MIE $\rightarrow$ (www.resic.info $\rightarrow$ MIE),

- those who read the first German draft, Dr. Jürgen Endres, Dr. Andreas Tunger-Zanetti, Laura Lots, Mara Griesehop, and Lukas Portmann (all Lucerne),

- Mara Griesehop (Lucerne) for double-checking the first English translation, and Dr. David West (Academic Translation Services) for completing the work,

- our colleague Rainer Diaz-Bone (Lucerne) for valuable advice and suggestions from his methodological consulting service at the University of Lucerne,

- our families and partners, who, through their encouragement, critical questions, and the provision of joys and surprises in everyday life, have played their own part in bringing this study to fruition.

All remaining errors are of course the responsibility of the authors.

Antonius Liedhegener

Gert Pickel

Anastas Odermatt

Alexander Yendell

Yvonne Jaeckel

Lucerne and Leipzig, 22 March 2021 
Prof. Dr. Antonius Liedhegener

University of Lucerne

Center for Religion, Economy and Politics (ZRWP)

Frohburgstr. 3 / PF 4466

$\mathrm{CH}-6002$ Lucerne

+41(0)412295913

antonius.liedhegener@unilu.ch
Prof. Dr. Gert Pickel

Leipzig University

Faculty for Theology

Martin-Luther-Ring 3

DE-04109 Leipzig

+49 (0)3419735463

pickel@rz.uni-leipzig.de 